\title{
EXAMINING DESIGN SIMPLICITY IN ARCHITECTURAL DESIGN OF PUBLIC CORE HOUSING SCHEMES IN ANAMBRA STATE OF NIGERIA
}

\section{Dr. Nnaemeka Bennet Christian Dillon Okoye ${ }^{1}$, Prof. Ikechukwu Onyegiri²} and Dr. Marcellinus Okafor ${ }^{3}$

\author{
${ }^{1}$ Department of Architecture, School of Environmental Design and Technology, Federal \\ Polytechnic Oko, Nigeria \\ E-mail: emii2him@gmail.com
${ }^{2}$ Department of Architecture, Faculty of Environmental Sciences, Imo State University, Owerri, Nigeria
E-mail: onyegiriikechukwu@gmail.com \\ ${ }^{3}$ Department of Architecture, Faculty of Environmental Sciences, Imo State University, \\ Owerri, Nigeria \\ E-mail: arcdrmuokafor@gmail.com
}

\begin{abstract}
Cite this article:
Okoye N.B.C.D. , Onyegiri I., Okafor M. (2021), Examining Design Simplicity in Architectural Design of Public Core Housing Schemes in Anambra State of Nigeria. Journal of Advanced Research and Multidisciplinary Studies 1(1), 60-117. DOI: 10.52589/JARMS-I1K3R38I.
\end{abstract}

\section{Manuscript History}

Received: 9 June 2021

Accepted: 9 July 2021

Published: 24 July 2021

Copyright $\odot 2020$ The Author(s). This is an Open Access article distributed under the terms of Creative Commons AttributionNonCommercial-NoDerivatives 4.0 International (CC BY-NC-ND 4.0), which permits anyone to share, use, reproduce and redistribute in any medium, provided the original author and source are credited.

\begin{abstract}
Studies identify dearth of affordable core houses for households who cannot afford whole houses. Architectural design characteristics affecting design simplicity have been found to positively influence core housing affordability. Despite this, documentation on whether design simplicity has been considered in the designs of existing core houses is lacking. This is required to check imputs in future designs. Study examined reflection of design simplicity in architectural design of existing public core housing schemes in Anambra State, Nigeria, using Mixed Method approach. Data were obtained from architectural drawings of existing prototypes, field observations and personal interview protocols. Observation schedules with "Yes" and "No" ratings were used in ascertaining reflection of the attribute in each of the 7 prototypes studied. It was found featuring only in 3 out of the 7 prototypes. For affordability improvement, the paper recommends inculcating the variables constituting design simplicity in future core housing design in Anambra State.
\end{abstract}

KEYWORDS: Architectural Design Characteristics, Design Simplicity, Housing affordability, Core housing schemes, Lowcost housing. 


\section{INTRODUCTION}

Globally, the ill-effects of dearth of adequate housing are known to be profound. Consequently, housing issues have been discussed in several global summits; such as the 1996 Habitat summit at Istanbul, the 2000 New York, United Nations Millennium Development Goals (MDGS) summit, the 2002 World Summit in Johannesburg and the 2005 La Havana, UN Sustainable Cities Documentation of Experience Programme (Okoye, Onyegiri \& Okafor, 2021 citing Ugonabo \& Emoh, 2013). One of the major issues confronting adequate housing provision is the subject of affordability. Housing affordability has been described as implying the ability of households to meet the expense of housing alongside other household needs (Hancock, 1993).

Majority of the public housing provisions, particularly in developing nations, have failed to deliver affordable housing. World Bank (2018) observes that demand for affordable housing in Nigeria is large and growing, in the face of a sizeable deficit of 17 million units. It also noted that majority of houses produced cater for the upper income households, leaving an acute housing shortage for households of the middle and lower income range. Anambra State, one of the states in Nigeria is experiencing the challenge in the provision of affordable housing. Households of low-income disposition are mostly affected. Ugonabo and Emoh (2013) and Eni (2015) confirm this, noting the critical need for the provision of adequate and affordable housing for the low-income people, a situation that has heightened housing scarcity in Anambra State. Government effort at housing provision, which has concentrated on the development of whole (full-provision/finished) houses types, has not yielded much fruit. The intervention made by it in provision of core houses, meant to provide affordable housing for those who cannot afford full-provision houses, has equally failed to record success, as the target group has not benefitted from the schemes.

The concept of core housing aims at providing habitable but austere compact spaces that in a multi-purpose fashion cater for the basic housing needs, while having the potential for easy ugprading and extension. Pandelaki and Shiozaki (2010) regard a core house as a small unit or permanent structure that is incomplete, with minimum livable space and facilities designed to be upgraded over time. Abrams (1964) explains core housing as a low-cost housing delivery strategy intended for households who cannot afford whole houses (fullprovision/finished), due to their lean income disposition. Likewise, Maly and Tamyo (2010) view core housing as a low-cost housing provision of minimal but habitable structures which households incrementally add on to while living there. In the implementation of the stategy, however, it has been noticed that in various cases the affordability advantage of this approach has been neglected through design. Studies: Faculty of Engineering and Architecture, University of Khartoum, Sudan (FEAUKS) (2010); Pandelaki and Shiozaki (2010); Gudeta (2010); Irouke, Ajah and Ivoke (2017), and Udoh (2018) attest to this, asserting that despite the affordability potential of this strategy, its implementation has been fraught with affordability challenges. Neglect of pertinent architectural design considerations in the design of core houses has been advanced as a major reason for this occurrence. This situation could result in targeted households of core housing being displaced by wealthier ones who ordinarily could afford whole houses (Napier, 2002). Pandelaki and Shiozaki (2010) are of the opinion that the high cost of building materials required in constructing houses, if not minimized through design of core houses, could cause a weakening of their affordability for the intended beneficiaries. 
Anambra State government in implementating the core housing strategy, built core houses and sold to people in some cases, while allocating serviced lands to others who bought and developed them with government approved prototypes. However, majority of these houses seem to be designed more as full-provision/finished houses than core houses judging from their physical appearances, and it is doubtful if they have satisfied the affordability requirements of the intended residents. Ajanlekoko (2001) opine that the catalogue of building (architectural) design variables, which have great impact on house price (hence its affordability) are controlled by the design process. The study affirms that parameters such as building size, building shape and building specifications (building material type finishes) have a lot to contribute in this vein. As such lack of attention to critical design considerations that enhance core housing affordability could have affected the outcome of the core housing schemes. Design simplicity has been identified among these notable considerations and studies: Ike (1996); Napier, (2002); Pandelaki and Shiozaki (2010); Maly and Tamyo (2012) Atamewan and Olagunju (2017) and Okoye, Onyegiri and Okafor (2021) have enumerated what constitutes this attribute. They include: (i) simplicity in size of initial floor area; (ii) simplicity in shape of initial house; (iii) simplicity in specification for wall material; and (iv) simplicity in specification for roof covering. Okoye, Onyegiri and Okafor (2021) have further established that this attribute positively and strongly influences core housing affordability.

However, knowledge is lacking on how the components of design simplicity have been reflected in the design of existing core houses, because they have not been investigated. Information from such investigations would be vital in the design of future core housing schemes, in order to know what areas to uphold or avoid for affordability improvement. The above scenario of knowledge gap and its implications fits the situation in the study area, Anambra State, where records are unavailable on how existing core housing schemes performed in respect of inculcation of this attribute in their designs. In an effort to close this gap, this study examined existing public core housing schemes in Anambra State with a view to determining if design simplicity has been reflected in them.

To achieve this, the following objectives were pursued, and they were meant to:

i) review literature on design simplicity in architectural design of core housing schemes; and

ii) ascertain if design simplicity is reflected in architectural design of existing public core housing schemes in Anambra State.

The following research questions were pursued in order to realize the objectives, namely:

i. What does design simplicity in architectural design of core housing schemes imply?

ii. Is design simplicity reflected in architectural design of existing public core housing schemes in Anambra State? 


\section{LITERATURE/THEORETICAL UNDERPINING}

\section{Core housing strategy in public housing provision}

Public housing has been described as government-provided or government-subsidized housing project(s) (Ibem, Anosike \& Azuh 2011). The purpose of public housing, according to Balchin, Isaac and Chen (2000) and Kolli and Putta (2014), is to assist those who cannot compete in the market place to own or have access to decent housing. However, public housing in its conventional setting of provision of whole (full-provision/finished) houses has been known to have suffered several setbacks in implementation including affordability. It is the shortcomings of the conventional public housing system in performance, particularly in provision of affordable housing for the low-income households that led to the conception of the core housing strategy. According to Napier (2002), an investigation of the roots of the core housing concept reveals that it was essentially a compromise which allowed governments to pull back from the provision of completed mass housing. By this strategy, government ironically provides less by giving opportunity for residents to add to and thus participate in the production of their own housing. This mode of construction (partialprovision) was interpreted to be as a result of lack of sufficient funds to build whole (fullprovision/finished), because of insufficient personal savings or appropriate financial assistance (Abrams, 1964). Core housing therefore arose out of an acknowledgement not only that governments could not afford whole houses (full provision) but also that most households could also not afford it.

Several studies: Abrams, 1964; Napier, 2002; Pandelaki and Shiozaki, 2010; Goethert, 2010; Maly \& Tamyo, 2012 and Okoye, Onyegiri \& Okafor, 2021 explain what core housing is. Abrams (1964) sees it as a building designed to be minimal in size and somewhat partially complete initially, which residents incrementally expand, in response to their evolving needs and economic ability. Maly and Tamyo (2012) explain the core house as an initial habitable but minimal (low-cost) structure which households add on to while living there. Pandelaki and Shiozaki (2010) regard a core house as a small unit or permanent structure that is incomplete, with minimum livable space and facilities, designed to be upgraded over time. Goethert (2010) notes that core houses begin as starter core shelters, in form of multi-purpose rooms or studio apartments, with basic kitchen/bath facilities adding that the owners are expected to control the expansion based on their needs and resources. Pandelaki and Shiozaki (2010) point out that core housing is meant to be an affordable and flexible way through which households can own their houses gradually, if they cannot afford to start and complete them (or buy whole ones) instantly. Importantly young families can move into a core house and contribute in upgrading and expanding it as family size increases. Generally, core housing strategy encourages the initial provision of minimal, partial, but habitable housing units (core houses) which households in occupation leverage on for upgrading and expansion, as funds improve and needs arise (Okoye, Onyegiri \& Okafor, 2021).

In the view of Okoye, Onyegiri and Okafor (2021), there appears to be a problem in defining the target group for core housing by simply using the income group stratification, because of the global ambiguity resulting from disparity in purchasing power. It seems safer to approach the definition of the intended residents from the perspectives of Abrams (1964), Napier (2002), Greene and Rojas (2008) and Pandelaki and Shiozaki (2010) that they are those who cannot afford whole (full-provision/finished) houses. This is because while it is convenient in some localities for some low-income/middle income to afford whole houses, it is only the 
high-income families than can do so in other places. It is therefore the approach of this study to consider the intended residents of core housing schemes in a locality as those who cannot afford whole houses irrespective of their income stratification.

\section{Core housing and housing affordability}

Milligan (2003) reckons that housing affordability, being widely used to evaluate housing costs impact on consumers, has been interpreted in many ways. However, the most general use of the term (Hancock, 1993) centres around consideration of the extent to which housing price for a given standard of housing impinges upon households" "income to live on", which is their capacity to meet total household need. Sharipah and Sidi (2011) observe that housing affordability measures the cost of house against the amount buyers can afford. In measuring housing affordability therefore, a standard is established in respect of which the proportion of income spent on housing is deemed unaffordable (Mutisya, 2015). According to Nwuba (2015), the ratio approach is the conventional and most widely used housing affordability measure.

Generally, outright house acquisitions through personal savings and mortgage systems of borrowing from financial organizations remain the main sources of homeownership finance. Majority of low-income earners have no access to upfront finances and as such personal savings is their most relevant financing source. Gudeta (2010) and Breimer (2011) reckon "house price-to-income ratio", which compares housing price with average annual income of a household, as the measure of the affordability of a housing unit obtained through personal savings. Grimmes (1976) and Feins and Lane (1981) cited in Ndubueze (2009) state the ratio as: house price should not exceed $2.5\left(2^{1} / 2\right)$ times of household's average annual income or 30 times of the household's average monthly income. A house acquired through personal savings is affordable therefore if house price (HP) $<$ or $=2.5 \mathrm{x}$ household's average annual income (HAAI) or $30 \mathrm{x}$ household's average monthly income (30 x HAMI or 30HAMI) (Okoye, Onyegiri \& Okafor, 2021). The study (Okoye, Onyegiri \& Okafor, 2021) equally views affordability measure for this house acquisition type as the relationship between HP and 2.5 HAAI or 30HAMI. It implies that households whose " $2 \frac{1}{2}$ times average annual income" are less than or equal to the price of the least of the whole house types in a place constitute the intended beneficiaries of core housing schemes acquired through personal savings. This is the situation in the study area, Anambra State.

Various studies reporting core housing schemes, such as: Pandelaki and Shiozaki (2010); Ibem (2011); Maly and Tamyo (2012) and Ibem, Aduwo and Ayo-Vanghan (2015) observe them as being affordable, but noting that the residents were mainly middle and high-income households and that they were acquired through mortgage. Where the houses were acquired without mortgages and the residents were of low-income dispositions, such as the case in Atamewan and Olagunju (2017), the houses were found not affordable. Furthermore, other studies: (FEAUKS) (2010); Pandelaki and Shiozaki (2010); Gudeta (2010); Irouke, Ajah and Ivoke (2017), and Udoh (2018) aver that the implementation of core housing has been fraught with affordability challenges despite its potential for affordability. The concern of this study is on core houses acquired through personal savings and not mortgages as is the case in the study area and occupied by households within the range of intending beneficiaries of core houses (who actually form the target group). 


\section{Architectural design characteristics affecting design simplicity and core housing affordability}

Design simplicity considers the purpose of the building from its essential, perhaps even primitive origin, portraying an honest and straight-forward use of materials and construction, and restraints in ornamentation (Esenwein 2016). Seeing the hut as a model to the elements of all buildings, the study notes that every building needs a foundation, an enclosure and a roof (the basics). Bradley (2011) looks at design simplicity from the point of view of freedom from complexity and intricacy, absence of pretentiousness or ornamentation and directness of expressions. Widewalls Editorial (2017) considers design simplicity as employing simple geometric shapes, without ornament or decoration, and focusing on a product's aspect of being useful rather than pleasing to the eye, although such focus on usefulness often brought pleasant aesthetics as well. Widewalls Editorial (2017) sees design simplicity as employing simple geometric shapes, without ornament or decoration, and focusing on a product's aspect of being useful rather than pleasing to the eye, although such focus on usefulness often brought pleasant aesthetics as well. Generally associated with design simplicity are natural textures of materials such as earth (brick, clay), harmonious colours (Esenwein, 2016). Ike (1996), links design simplicity with Functionalism theory in Architecture; making a case for implementation of affordable spaces, simple practical forms and use of simple inexpensive building materials in portraying this attribute. Simple cost-saving measures in line with design simplicity in implementation of low-cost housing include affordable-space of not more than $36 \mathrm{~m}^{2}$ and simple geometrical forms (squares, rectangles) (Ike, 1996) and minimum acceptable space requirement of $7.2 \mathrm{~m}^{2}$ per person which translates to $36 \mathrm{~m} 2$ for a household of 6 persons (Pandelaki and Shiozaki, 2010). Pandelaki and Shiozaki (2010) note that simple design (design simplicity) promotes inexpensiveness of core houses, and that it can be achieved through the reduction of house floor area and decreasing of building material specification (brick walls without plaster, cement/sand screed floor and corrugated asbestos sheets and clay tiles for roof).

Atamewan and Olagunju (2017) in the study of incremental construction (core housing) for low-income housing delivery in Bayelsa State in Nigeria realized that the low-income people prefer to use locally sourced traditional materials such as earth (clay) for construction of walls and roof. Considering the above, this study agrees with VanEenoo (2011) that the one thing common to all notions of design simplicity is that all definitions refer to some kind of reduction, basically in size of house, value of building materials and other considerations. In Okoye, Onyegiri and Okafor (2021), the following variables (architectural design characteristics) of design simplicity were isolated being the three, based on the judgement of the Head of the quantity surveying department of the Anambra Housing Development Corporation (ASHDC) and the researchers' experience, that mostly affected core house prices. and the researcher's experience, namely: (i) simplicity in size of initial floor area; (ii) simplicity in shape of initial floor plan; and (iii) simplicity in specification for roof covering.

Studies abound on the fact that the attribute design simplicity promotes core housing affordability, and the variables for measuring it has been outlined above. The following studies: Abrams (1964); Ike (1996); Faculty of Engineering and Architecture, University of Khartoum, Sudan (FEAUKS, 2010); Pandelaki and Shiozaki (2010); Gattoni, Goethert and Chavez (2011); Breimer (2011); University of Minnesota Centre for Urban and Regional Affairs (UMCURA) (2015); Atamewan and Olagunju (2017) and Okoye, Onyegiri and Okafor (2021) have well reported on this subject. Nevertheless, there is need to know how 
this attribute was represented in architectural design of existing core housing schemes. This knowledge is needed in furnishing architects and other design professionals with apt information for planning future core housing schemes. This is in order to avoid compromising the due reflection of this vital affordability attribute.

\section{Theoretical framework}

Maslow's Theory on Hierarchy of Needs has been chosen as the theoretical basis for this study, which examines design simplicity in architectural design of existing public core housing schemes in Anambra State of Nigeria. The study was set to inquire if design simplicity is reflected in architectural design of existing public core housing schemes in Anambra State. In various studies: Ike (1996), Pandelaki and Shiozaki (2010); Bradley (2011); Esenwein (2016) and Widewalls Editorial (2017), a common ground has been established that all notions of design simplicity refer to some kind of reduction of the building's elements (basically in size of house, shape of house and value of building materials and other considerations), and in focusing on the building's primary function. The hut was considered a basic model for buildings, having foundation, wall and roof.

Maslow's Theory on Hierarchy of Needs opines that people are motivated by a desire to satisfy their basic needs first before strongly desiring the satisfaction of secondary needs. A.H. Maslow in his book "Motivation and Personality" propounds that the most basic level of needs must first be met before the individual strongly desires, or focuses motivation upon the secondary needs (Maslow, 1970). Maslow explained the hierarchy of needs to consist of five levels of cognitive needs, which he ranked according to order of importance (Figure 1). The needs according are: psychological needs, safety needs, belongingness and love needs, esteem needs, and self-actualization needs. Commenting on this theory, Zavei \& Jusan (2010) observe that the consideration of certain human needs as more basic and critical than others is proper, stressing the importance of this factor as planning tool. Maslow's Theory on Hierarchy of Needs sees the physiological needs as the most basic needs of man and posits that they should be met first before the other ones, in the order of: safety, social belongingness, esteem and self-actualization needs. The physiological needs, which consist of the physical requirements for human survival, namely; breathing, water, food, sleep, clothing and shelter needed to be prioritized over others as they will lead to body malfunction and possibly death if not met. Shelter, connoting protection from intrusions and harsh weather elements, is the physiological need that essentially has to do with housing. Greene and Rojas (2008) supports this by opining that the primary function of a house from the household's point of view is to provide protection against harsh weather conditions (cold, rain, sun and wind), and from unwarranted physical access. The study considers the achievement of this purpose of shelter as the first priority after accessing land. Shelter, being placed at the base of Maslow's pyramid or triangle, implies that its provision is the basic function of buildings as such without achieving affordable housing for the households, there will be no grounds to talk about other housing needs (Salami, 2011). 


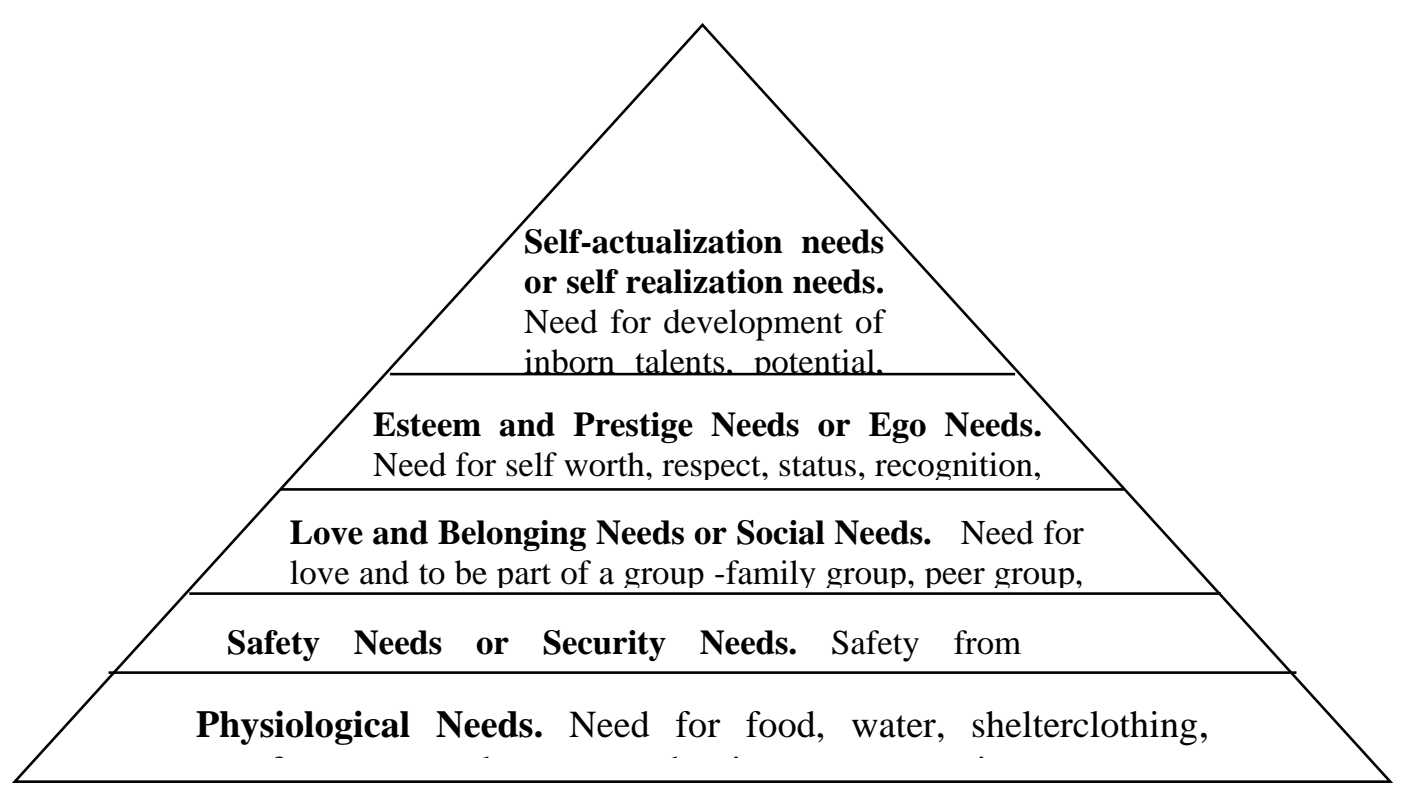

Figure 1: Abraham Maslow's Hierarchy of Needs Triangle

Source: Onah (2015)

This study as such hinges on the theoretical construction between the provision of simple shelters for the basic function of protection, identified from Maslow's Hierarchy of Needs theory as the basic need of the housing users and the core housing principle of starting with a simple structure (core house) that meets the household's basic need of shelter, for affordability reasons (Okoye, Onyegiri \& Okafor, 2021). It is after this has been satisfied that other needs can be met, as expansion goes on. Therefore, Maslow's Hierarchy of Needs theory guides this study (in conjunction with the core housing concept) on steps to follow in order to understand how the essential attribute of core housing affordability has been reflected in architectural design of the prototypes under study. In order words, it supports this study in finding out if design simplicity, which focuses on providing for household's most basic needs (simple structure that provides shelter), influenced the designs.

\section{METHODOLOGY}

This study covers the existing public core housing estates conceived and built by the Federal and State governments in the public housing programme in Anambra State, Nigeria. Confirmation was obtained from preliminary investigation that the core houses developed at Federal Low-Cost Housing Estate, Trans-Nkisi, Onitsha and AHOCOL Niger Close Housing Estate, G.R.A, Onitsha are virtually non-existent, as they have been partially/totally demolished respectively. The surviving ones are located in Awka capital city. Awka capital city, which is the capital city of Anambra State of Nigeria is therefore the study area for this research. Anambra State (Figures 1 and 2) is one of the 36 states of the Nigerian Federation and one of the five states in the South-East Geo-political zone of the country, Nigeria (United Nations Human Settlements Programme, UN-HABITAT, 2009) 


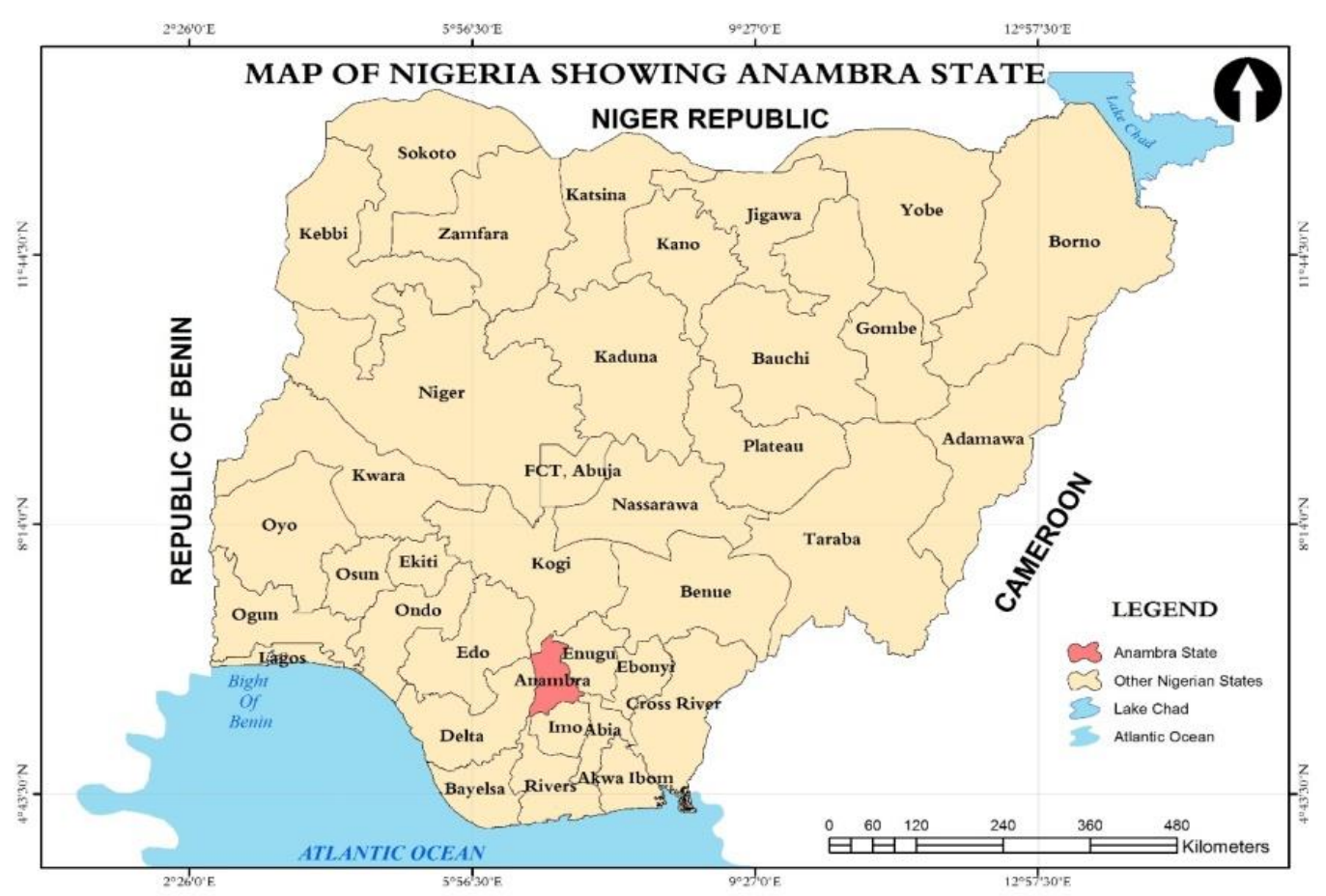

Figure 1: Map of Nigeria Showing Anambra State.

Source: Office of the Surveyor General of the Federation, Abuja 2012.

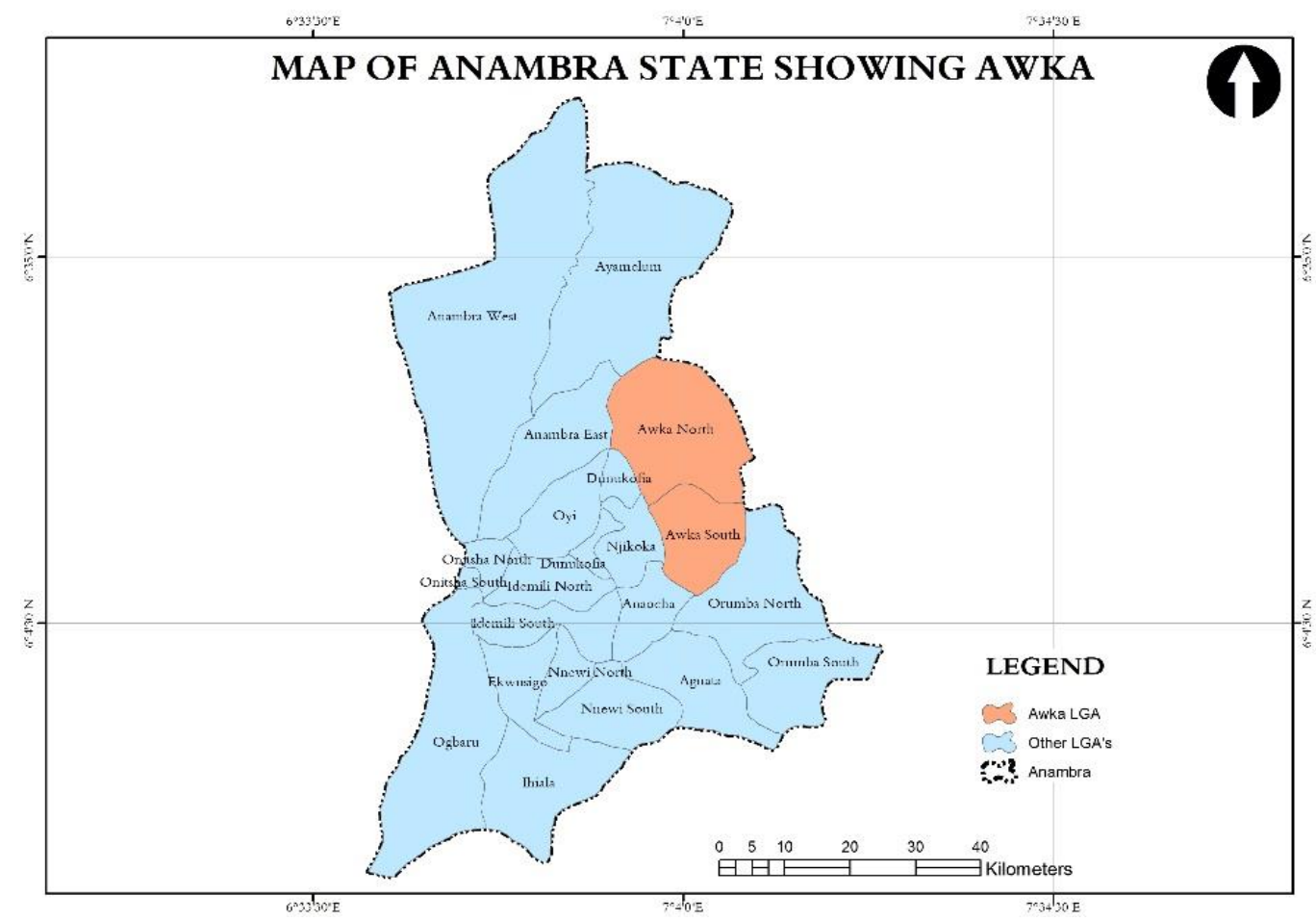

Figure 2: Map of Anambra State Showing Awka.

Source: Office of the Surveyor General of the Federation, Abuja 2012. 
Awka capital city is located at about 300 metres above sea level and is fairly level, having two ridges which appear in a north - south direction. About 150 metres above sea level, however, the minor ridge rises at Ifite - Awka. It is this area and the plain land surrounding it that forms the area under consideration which is known as Awka capital city (UN-HABITAT, 2009). This area is reported by UN-HABITAT (2009) to be underlaid with a thick sequence of shale and sand stones which was formed during the Paleocene age. Clay and sands that contain lignite cover the shale and sand stones. Loamy, fine white sands and laterite (which is loose and poorly compacted and easilyeroded) are equally available. This area is in the rain forest zone of Nigeria. Consistent agriculture and impactful economic activities on the land have resulted in the vegetation being changed to a mixed savannah type. In residential places and along stream lines, rain forest trees including Mango, Orange, Iroko, Palm, Cola nut and Coconut trees could be found. UN-HABITAT (2009) observes that high temperatures are usually prevalent in Awka capital city, which has a normal range of about $27-28^{0} \mathrm{C}$ and peaks to about $35^{\circ} \mathrm{C}$ during the hottest times, spanning between February and April. From the midrainy season up till the harmattan times, is the coolest weather, from mid-July up to December and to early January, which promotes outdoor activities. High humidity and rainfall are equally withnessed in this area. UN-HABITAT (2009) classifies Awka capital city as located within the tropical wet climatic zone, with marked wet and dry seasons. Annual rainfall from 1979-1989 was recorded as 1,485.2 $\mathrm{mm}$ and it has a mean monthly figure of 50mm. Rain fall is witnessed for about eight of the twelve months of the year, while the remaining four months experience dryness, being pioneered by the activities of the two predominant winds in this area, known as the south-west monsoon wind and the north-east trade wind. The south-east monsoon wind comes from the Atlantic ocean, the north-east trade wind from the Sahara desert. The peculiar harmattan period, which is characterized by a very dry and dusty atmosphere, is witnessed between the months of November and February and is predominately harsh for about two weeks.

Concerning the population of Awka capital city, the National Population Commision of Nigeria, NPC, (2006) estimated it as 113,660. This figure is made up of Awka (86,593), Amawbia $(21,773)$ and Okpuno $(5,294)$. Imputing the annual growth rate of $3.2 \%$, in line with NPC (2006), 220, 094 was projected as the population for the year 2020. Looking at the settlement pattern in the Awka capital city, two distinct segments are identified. These are the built-up traditional setting and the sparsely developed/developing areas around it. The traditional setting is seen as overcrowded, unplanned, and without good road systems. Open lands surrounding the compounds are used for agriculture. Knowledge of the settlement characteristics is crucial for achievement of proper planning. In Awka town itself, two major components of settlements are noticed. The first is the older indigenous settlement with a palace and a market square at the centre which provides sufficient open spaces for recreation, religious, socio-cultural and economic activities. Individual family compounds, compact in nature, walled and linked up with untarred roads and pathways are also noticeable. The second is the newly developing area merging into the old settlement but separated by the Enugu-Onitsha expressway.

Mixed method research design was adopted for this study in view of the types of data required. The residents of all existing public core housing estates (federal government and state government owned) developed in the public housing programme of Anambra State formed the population of the study. Okoye, Onyegiri \& Okafor (2021) report that a total number of 7 core housing estates, having 1,173 housing units (all bungalows), and 1,430 
dwelling units, were developed in Anambra State. As has been earlier observed, the core houses developed at Federal Low-Cost Housing Estate, Trans-Nkisi, Onitsha and AHOCOL Niger Close Housing Estate, G.R.A, Onitsha have been partially/totally demolished respectively. The estates under study therefore are the remaining 5 estates developed by the Anambra State Home Ownership Company Limited (AHOCOL), Awka and the Anambra State Housing Development Corporation (ASHDC), Awka, comprising of 953 housing units and 1,210 dwelling units (257 were of the semi-detached type with 2 dwelling units occupied by different households) (Okoye, Onyegiri \& Okafor, 2021). The intended residents for the core houses were determined by computing the maximum monthly income of households who cannot afford whole houses. The affordability yardstick of not more than 2.5 times household's annual income (Grimmes, 1976 and Feins and Lane, 1981 cited in Ndubueze, 2009) was applied because Anambra housing policy is based on outright house purchase, without mortgage financing (see Personal interview protocol of the Head of Estate Management department of ASHDC during pilot survey - Appendix B). The price of the least of the whole houses developed in Anambra State as obtained from the personal interview protocol of the Head of Quantity Surveying department of ASHDC during the pilot survey (Table 1 and Appendix C) was also applied (Okoye, Onyegiri \& Okafor, 2021). A total of 6 Million Naira $(\$ 15,483.87)$ was obtained.

Table 1: Average Land/Building Costs of 1-Bedroom, 2-Bedroom and 3-Bedroom Full-Provision/Finished House Types within the City as at the Year 2016

\begin{tabular}{cllll}
\hline S/N & Prototype & Building Cost $(\mathbf{N})$ & $\begin{array}{l}\text { Land } \\
\text { Cost }(\mathbf{N})\end{array}$ & $\begin{array}{l}\text { Selling } \\
\text { Price }(\mathbf{N})\end{array}$ \\
\hline 1. & 1-bedroom & $2 \mathrm{M}\left(300 \mathrm{~m}^{2}\right)$ & 4 million & 6 million \\
2. & 2-bedroom & $3 \mathrm{M}\left(360 \mathrm{~m}^{2}\right)$ & 4.8 million & 7.8 million \\
3. & 3-bedroom & $4.1 \mathrm{M}\left(450 \mathrm{~m}^{2}\right)$ & 6.3 million & 10.4 million \\
\hline
\end{tabular}

Source: Field work (2016), Compiled from Infomation obtained from the Head of the Quantity Surveying Department, Anambra State Housing Development Corporation, Awka

By imputing 6 Million Naira $(\$ 15,483.87)$ and 2.5 x Household Annual Income as derived from the literature review 2.2 - (Okoye, Onyegiri \& Okafor, 2021), the figure N200, 000 (\$516.13) was realized as the maximum monthly income of households who cannot afford whole houses and therefore the intended residents for the core houses. The interest of this study is not on all the residents but only those who fall into the group of those intended for the core housing scheme. The residents whose average monthly incomes do not exceed N200, 000 (\$516.13) were then selected to form the group of intended residents of the core housing schemes. During the pilot survey, out of the total 1,210 dwelling units (households), 540 dwelling units (households) were isolated and noted as belonging to the group of intended residents for the core houses. Taro Yamane's formula was used to derive the sample size of 230. This was consequently distributed according to the contribution each estate/prototype is making to the total population of 540 dwelling units, through proportionate stratified random sampling procedure (Table 2). 
Table 2: List of Existing Public Core Housing Estates in Anambra State for Study According to Prototypes/Dwelling Units

\begin{tabular}{|c|c|c|c|c|c|}
\hline $\mathbf{S} / \mathbf{N}$ & Name of Estate & $\begin{array}{c}1- \\
\text { bedroom }\end{array}$ & $\begin{array}{c}2- \\
\text { bedroom }\end{array}$ & $\begin{array}{c}\text { 3- } \\
\text { bedroom }\end{array}$ & $\begin{array}{c}\text { Total } \\
\text { Dwelling } \\
\text { Units } \\
\end{array}$ \\
\hline 1. & $\begin{array}{l}\text { AHOCOL Think Home Estate } \\
\text { Phase 1, Agu-Awka, Awka } \\
\text { (PROTOTYPE AHOCOL 1) }\end{array}$ & & & 19 & 19 \\
\hline 2. & $\begin{array}{l}\text { AHOCOL Think Home Estate } \\
\text { Phase 2, Agu-Awka, Awka } \\
\text { (PROTOTYPE AHOCOL 2) }\end{array}$ & & & 42 & 42 \\
\hline 3. & $\begin{array}{l}\text { AHOCOL } \quad \text { Oganiru } \\
\text { Estate, }\end{array} \begin{array}{l}\text { Agu-Awking } \\
\text { (PROTOTYPE AHOCOL 3) }\end{array}$ & & & 26 & 26 \\
\hline 4. & $\begin{array}{l}\text { AHOCOL Inner City Layout, } \\
\text { Nkwelle, Awka (PROTOTYPE } \\
\text { AHOCOL 4) }\end{array}$ & & 3 & & 3 \\
\hline 5. & $\begin{array}{l}\text { ASHDC Ngozika Housing Phase } \\
\text { 1, Awka } \\
\text { (PROTOTYPES ASHDC 1, } 2 \text { and } \\
\text { 3) }\end{array}$ & 49 & 45 & 46 & 140 \\
\hline & Total & 49 & 48 & 133 & 230 \\
\hline
\end{tabular}

Source: Fieldwork (2016)

The existing public core house prototypes in Anambra State, shown in Table 3, is made up of the following: (i) semi-detached 3-bedroom bungalow at AHOCOL Phase (AHOCOL 1) - 19 dwelling units; (ii) semi-detached 3-bedroom bungalow at AHOCOL Phase 2 (AHOCOL 2) 14 dwelling units; (iii) detached 3-bedroom bungalow at AHOCOL Oganiru Housing Estate, Agu-Awka (AHOCOL 3) - 26 dwelling units; (iv) detached 2-bedroom bungalow at AHOCOL Inner City Layout, Nkwelle, Awka (AHOCOL 4) - 3 dwelling units; (v) detached 1-bedroom bungalow at ASHDC Ngozika Housing Estate, Phase 1, Ikwodiaku, Awka, (NGOZIKA 1) - 49 dwelling units; (vi) detached 2-bedroom bungalow at ASHDC Ngozika Housing Estate, Phase 1, Ikwodiaku, Awka, (NGOZIKA 2) - 45 dwelling units; and (vii) detached 3-bedroom bungalow at ASHDC Ngozika Housing Estate, Phase 1, Ikwodiaku, Awka, (NGOZIKA 3) - 46 dwelling units. 
Table 3: $\quad$ List of Existing Public Core House Prototypes in Anambra State Showing Number of Dwelling Units

\begin{tabular}{|c|c|c|}
\hline $\mathbf{S} / \mathbf{N}$ & CORE HOUSE PROTOTYPE & $\begin{array}{c}\text { NUMBER OF } \\
\text { DWELLING UNITS }\end{array}$ \\
\hline 1. & $\begin{array}{l}\text { Semi-detached 3-bedroom bungalow at AHOCOL } \\
\text { Phase } 1\end{array}$ & 19 \\
\hline 2. & $\begin{array}{l}\text { Semi-detached 3-bedroom bungalow at AHOCOL } \\
\text { Phase } 2\end{array}$ & 42 \\
\hline 3. & $\begin{array}{l}\text { Detached 3-bedroom bungalow at AHOCOL } \\
\text { Oganiru Housing Estate, Agu-Awka (AHOCOL 3) }\end{array}$ & 26 \\
\hline 4. & $\begin{array}{l}\text { Detached 2-bedroom bungalow at AHOCOL Inner } \\
\text { City Layout, Nkwelle, Awka (AHOCOL 4) }\end{array}$ & 3 \\
\hline 5. & $\begin{array}{l}\text { Detached 1-bedroom bungalow at ASHDC Ngozika } \\
\text { Housing Estate, Phase 1, Ikwodiaku, Awka, } \\
\text { (NGOZIKA 1) }\end{array}$ & 49 \\
\hline 6. & $\begin{array}{l}\text { Detached 2-bedroom bungalow at ASHDC Ngozika } \\
\text { Housing Estate, Phase 1, Ikwodiaku, Awka, } \\
\text { (NGOZIKA 2) }\end{array}$ & 45 \\
\hline $7 .$. & $\begin{array}{l}\text { Detached 3-bedroom bungalow at ASHDC } \\
\text { Ngozika Housing Estate, Phase 1, Ikwodiaku, } \\
\text { Awka, (NGOZIKA 3) }\end{array}$ & 46 \\
\hline
\end{tabular}

Source: Fieldwork (2016)

Relevant data for the study were obtained from: (i) related literary works; (ii) architectural drawings of existing public core house prototypes in Anambra State (reproduced from Archival Records of Anambra State Housing Development Corporation, Awka) which consists of site plans, floor plans and elevations; (iii) photographic images of the prototypes; (iv) building materials/finishes specification schedule and (v) personal interview protocols. Data collection was carried out between the months of February 2016 and October 2017. The following variables were identified from literature review (Okoye, Onyegiri \& Okafor, 2021) as constituting architectural design characteristics affecting design simplicity as it relates to core housing schemes, namely: (i) simplicity in size of initial floor area; (ii) simplicity in shape of initial floor plan; and (iii) simplicity in specification for roof covering.

Data was presented through the use of figures depicting architectural drawings and, plates showing photographic images. In the study of housing affordability in Kenya, Mutisya (2015) had used a rating of 1,2 and 3 values for superior design, moderate design and inferior design respectively, to measure the qualitative variable "house design" in terms of size of house and building material/finishes specifications. Similarly, in this study data on ascertaining the reflection of the qualitative attribute "design simplicity" of the existing public core housing schemes in Anambra State were analysed by applying a rating of "Yes and "No" values to measure its inclusion or deficiency respectively, in terms of the variables: (i) simplicity in 
size of initial floor area (SSF); (ii) simplicity in shape of initial floor plan (SSP); and (iii) simplicity in specification for roof covering (SSR) (see Observation Schedule, Appendix A).

\section{RESULTS/FINDINGS}

\section{Results}

\section{Objective 1: to review literature on design simplicity in architectural design of core housing schemes}

Review of literature on design simplicity in architectural design of core housing schemes has been presented in the literature review section in 2.3. The following variables (characteristics) were found to compose design simplicity in architectural design of core housing schemes, namely: (i) simplicity in size of initial floor area; (ii) simplicity in shape of initial floor plan; and (iii) simplicity in specification for roof covering.

Objective 2: to ascertain if design simplicity is reflected in architectural design of existing public core housing schemes in Anambra State

The result on ascertaining if design simplicity is reflected in architectural design of existing public core housing schemes in Anambra State is presented according to the various prototypes and then summarized. Prototype 1 (Semi-Detached 3- bedroom bungalow at AHOCOL phase 1) and Prototype 2 (Semi-Detached 3- bedroom bungalow at AHOCOL phase 1) are presented together since they share typical site plans, floor plans and elevations of the initial cores and the expansions as well as building materials/finishes specification schedule. Their photographic images were however shown differently since they are personalized. The two prototypes were also separated in the result summary. 
Prototype 1 and Prototype 2: Semi-Detached 3- bedroom bungalow (core house) at AHOCOL phase 1 and AHOCOL phase 2 (AHOCOL 1 and AHOCOL 2)

(a) Architectural drawings

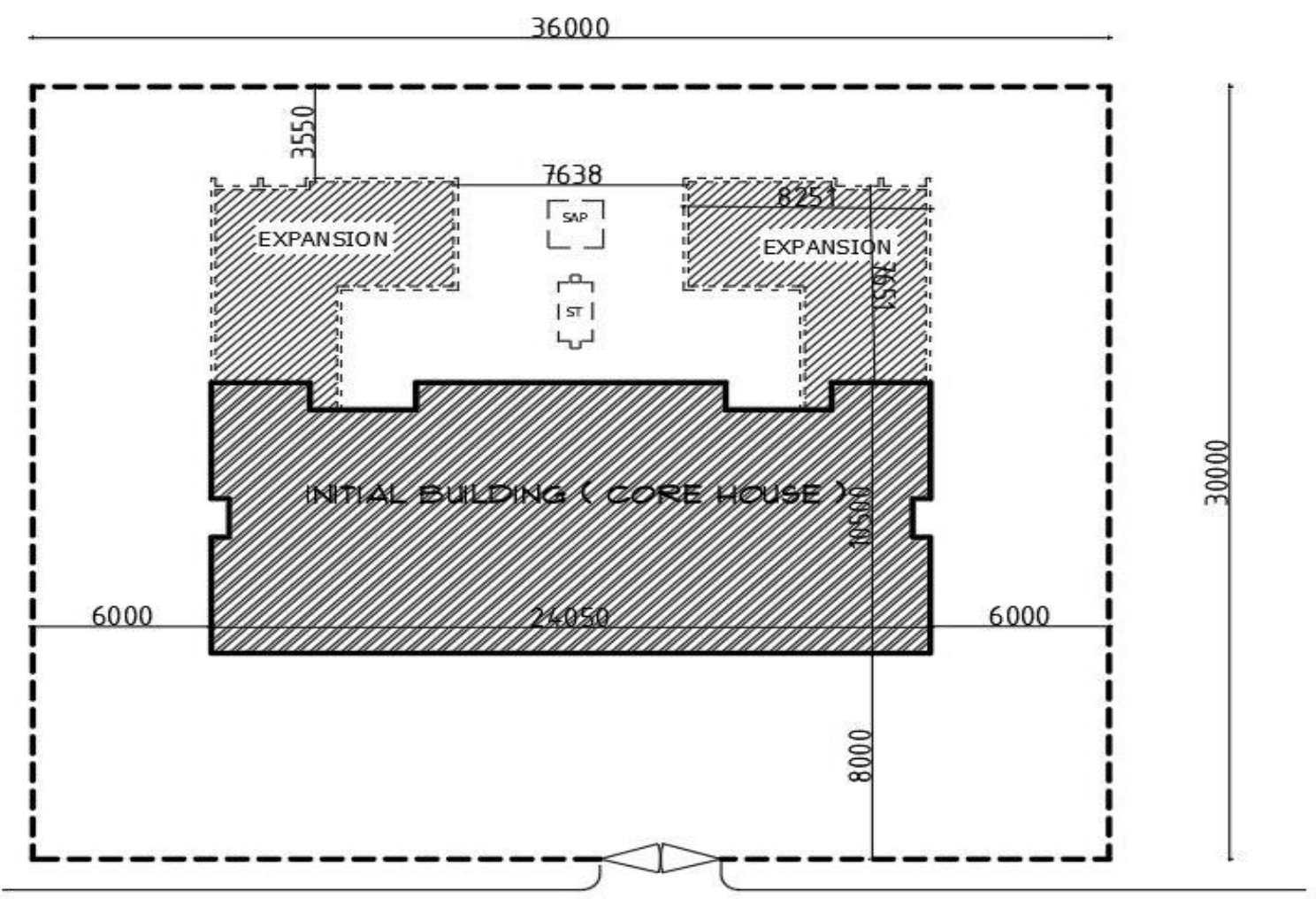

\section{SITE PLAN}

\begin{tabular}{|c|c|}
\hline \multicolumn{2}{|r|}{ LEGEND } \\
\hline --ー- & SITE (PLOT) BOUNDARY \\
\hline & EXPANSION LAYOUT \\
\hline XIPIIIIA & INITIAL BUILDING \\
\hline $\begin{array}{l}\Gamma-7 \\
\llcorner A]\end{array}$ & SEPTIC TANK \\
\hline |ח & SOAKAWAY \\
\hline$\overline{\overline{-}}$ & ACCESS ROAD . \\
\hline
\end{tabular}

\begin{tabular}{|l|}
\hline AREA DISTRIBUTION \\
\hline Area of Plot $\ldots \ldots \ldots \ldots$ \\
Proposed area of Building (Area Built) -250.00 SQ. MTRS. \\
Percentage Built up $\ldots-23.40 \%$ \\
Percentage Un-built $\ldots-76.60 \%$ \\
\hline
\end{tabular}

Figure 3: Site plan of the Semi-detached 3- Bedroom Bungalow at AHOCOL Phase 1 and AHOCOL Phase 2 (AHOCOL 1 and AHOCOL 2).

Source: Field Work (2017). Reproduced from Archival Records of Anambra State Housing Development Corporation, Awka 
Figure 3 is the site plan of the semi-detached 3-bedroom bungalow (core house) developed at AHOCOL 1 and AHOCOL 2. As can be seen from the Legend the darker-shaded portion depicts the initial 3-bedroom core house, while the lighter-shaded portion shows the expansion layout.

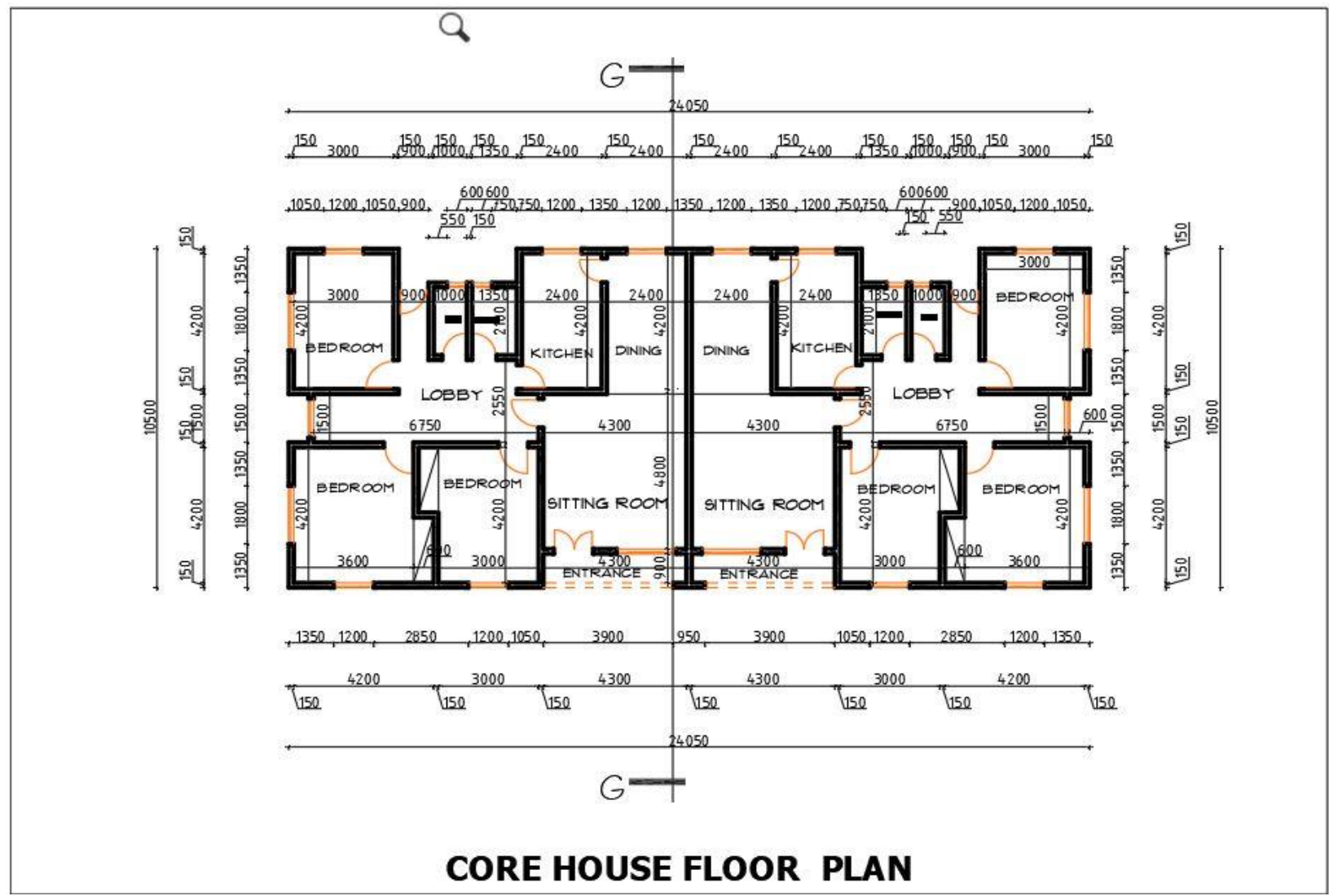

Figure 4: $\quad$ Floor plan of Initial Core, the Semi-detached 3 - Bedroom Bungalow at AHOCOL Phase 1 and AHOCOL Phase 2 (AHOCOL 1 and AHOCOL 2)

Source: Field Work (2017). Reproduced from Archival Records of Anambra State Housing Development Corporation, Awka.

Figure 4 is the floor plan of the semi-detached 3-bedroom bungalow (core house) developed at AHOCOL 1 and AHOCOL 2. 


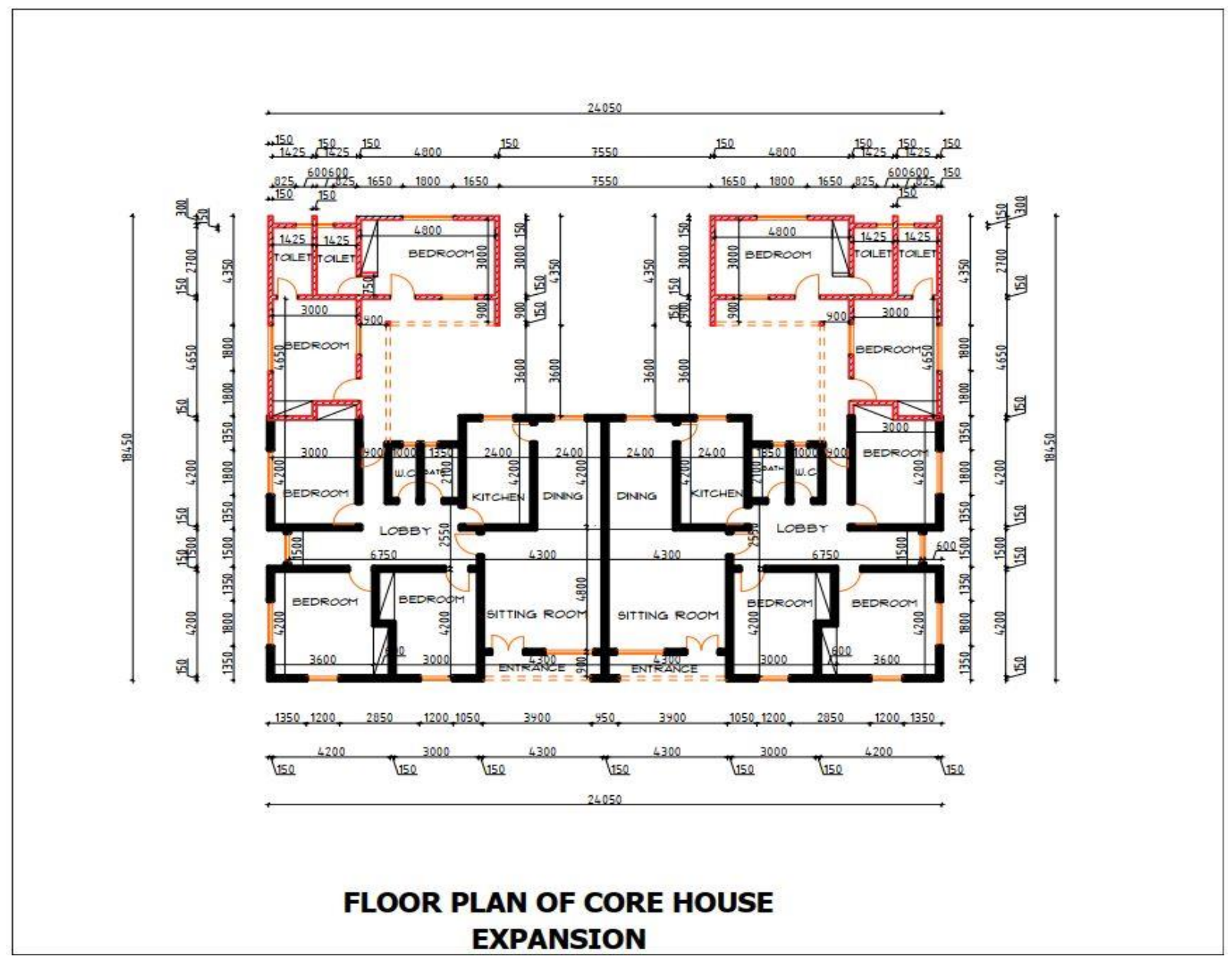

Figure 5: Floor plan for Core House Expansion, the Semi-detached 3- Bedroom Bungalow at AHOCOL Phase 1 and AHOCOL Phase 2 (AHOCOL 1 and AHOCOL 2)

Source: Field Work (2017). Reproduced from Archival Records of Anambra State Housing Development Corporation, Awka.

Figure 5 is the floor plan for core house expansion of the semi-detached 3 - bedroom bungalow (core house) developed at AHOCOL 1 and AHOCOL 2. 


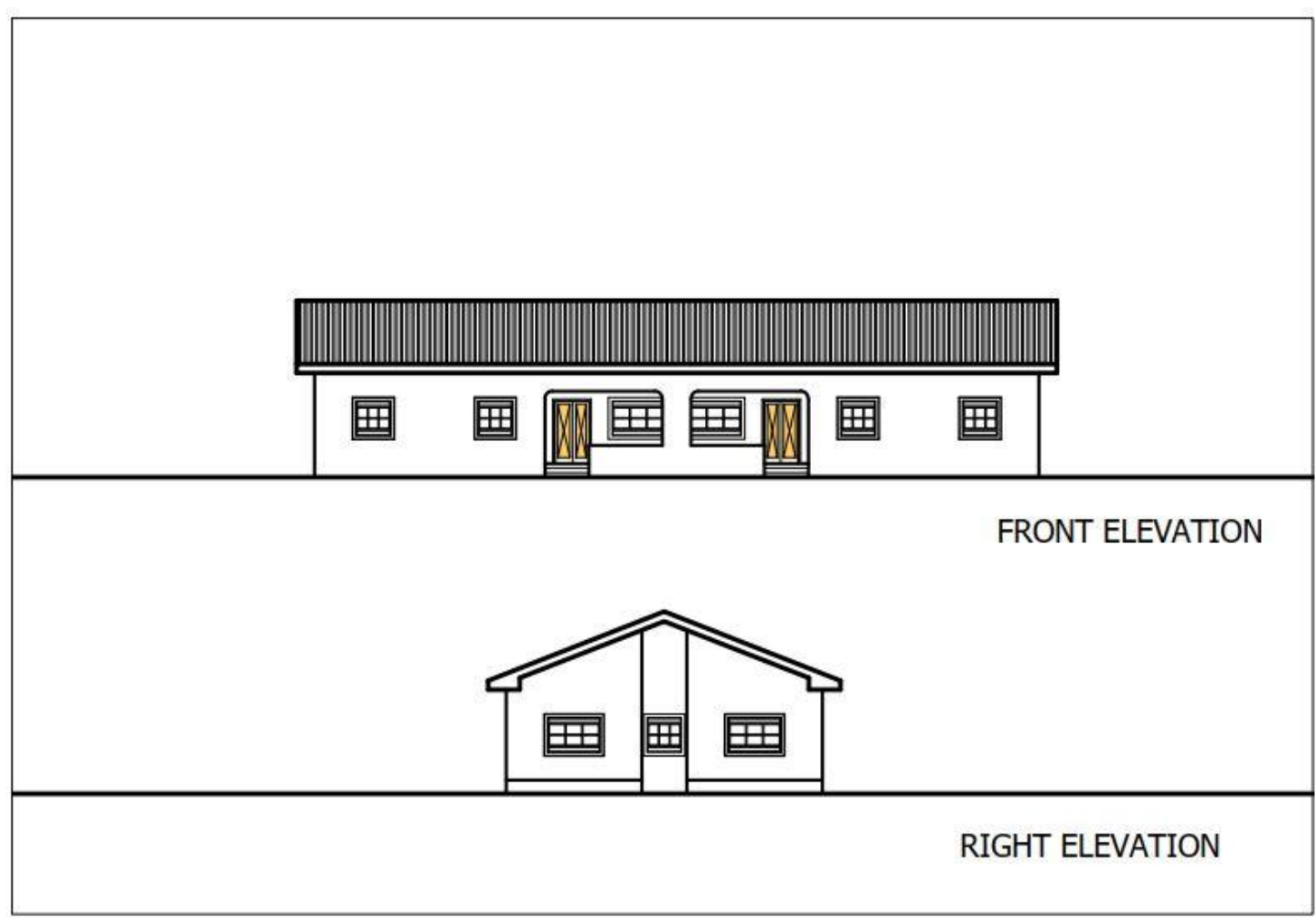

Figure 6: Front and Right Side Elevation, the Semi-detached 3- Bedroom Bungalow at AHOCOL Phase 1 and AHOCOL Phase 2 (AHOCOL 1 and AHOCOL 2)

Source: Field Work (2017). Reproduced from Archival Records of Anambra State Housing Development Corporation, Awka.

Figure 6 is the fornt and right side elevation of the semi-detached 3 - bedroom bungalow (core house) developed at AHOCOL 1 and AHOCOL 2. 
(b) Photographic images

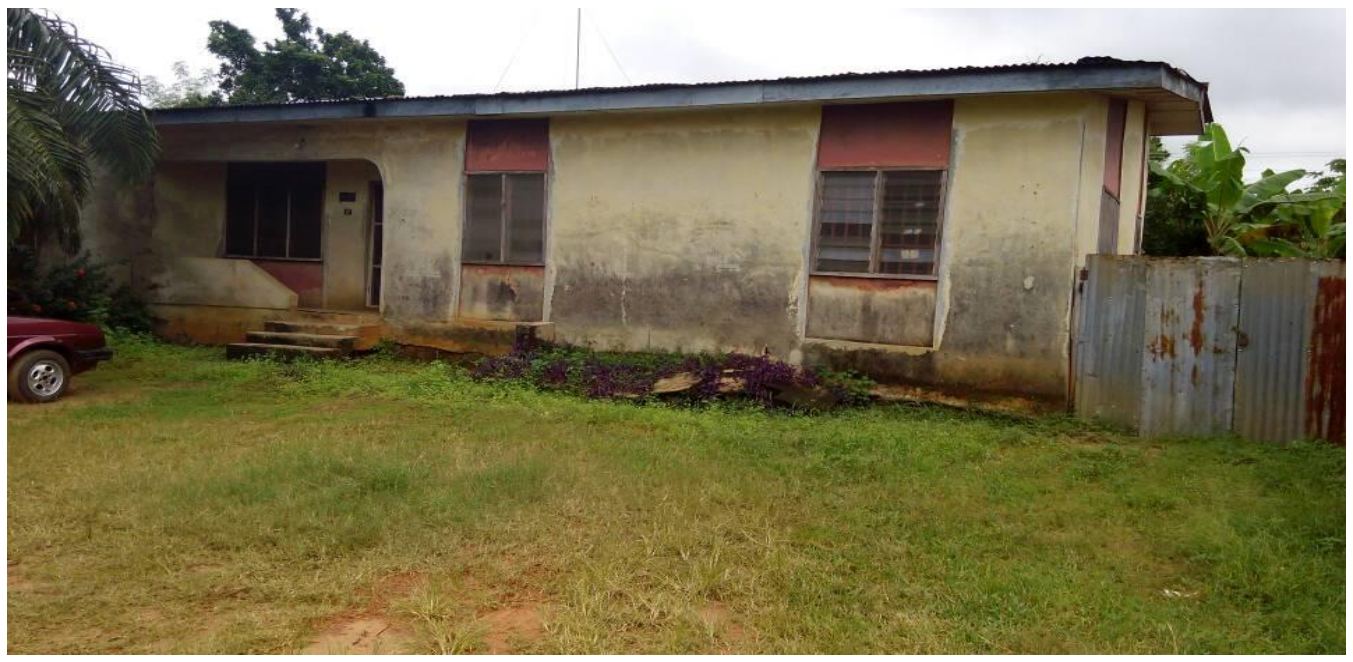

Plate 1: Photographic Image of the Semi-detached 3- Bedroom Bungalow at AHOCOL Phase 1 (AHOCOL 1) showing its appearance as a full-provision house rather than a partial-provision type (core house).

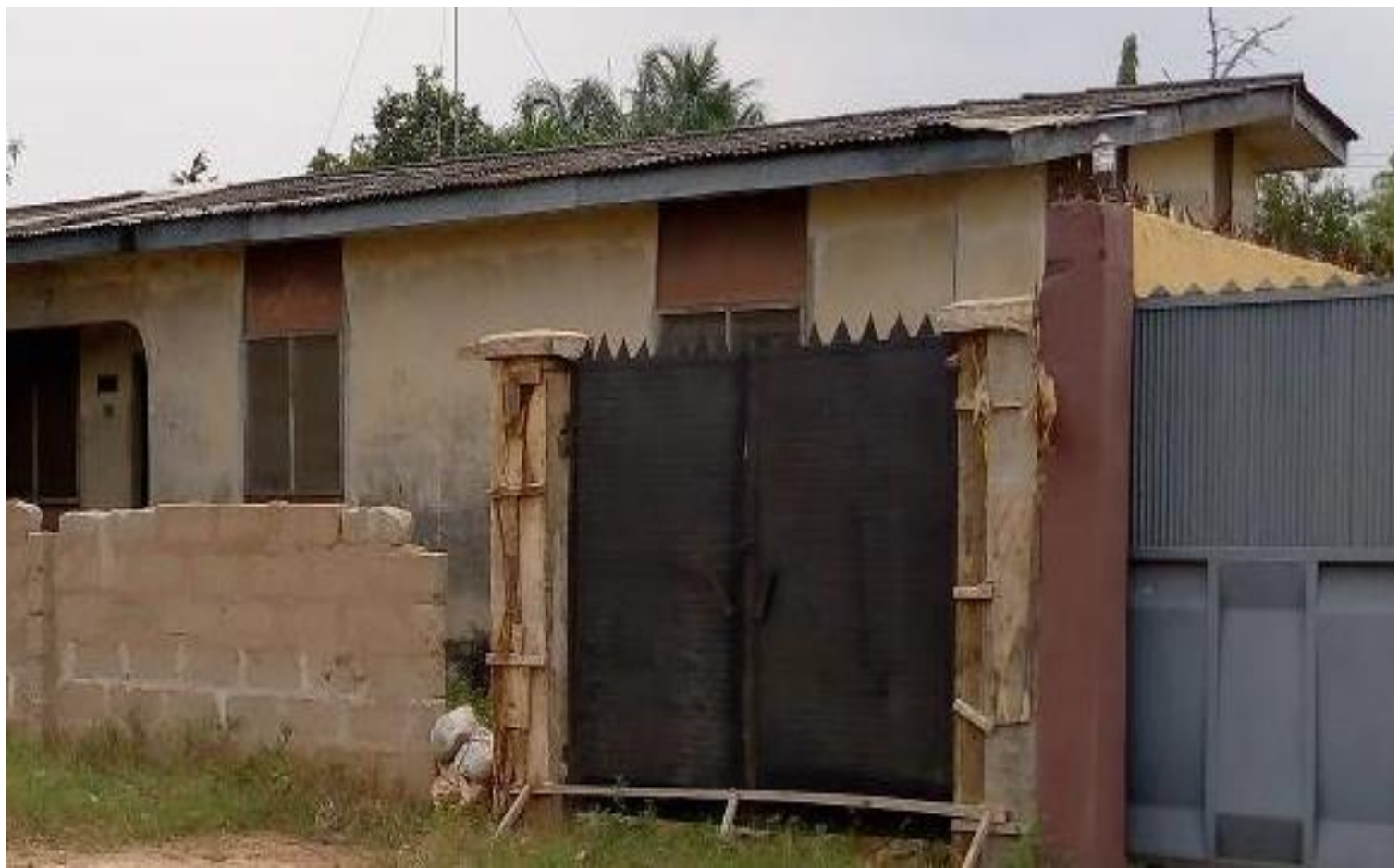

Plate 2: Photographic Image of the Semi-detached 3-Bedroom Bungalow at AHOCOL Phase 2 (AHOCOL 2) showing Cement Block Wall Material and Corrugated Asbestos Sheets as Roof Covering. 
(c) Building materials/finishes specification schedule

Table 4 is the building materials/finishes specification schedule of the semi-detached 3bedroom bungalow (core house) developed at AHOCOL 1 and AHOCOL 2.

Table 4: Building Materials/Finishes Specification Schedule

\begin{tabular}{ll}
\hline Building Element & \multicolumn{1}{c}{ Building Material/Finish } \\
\hline Wall & $150 \mathrm{~mm}$ sandcrete block \\
Roof covering & Asbestos roofing sheets \\
Floor finish & Sand/cement screed \\
& \\
\hline
\end{tabular}

Source: Fieldwork (2017). Compiled from the Architectural Drawings of Existing Core House Prototype obtained from Anambra State Housing Development Corporation, Awka and Field Observation.

(c) Result on asertaining the attribute "design simplicity" in architectural design of the Semi-detached 3- Bedroom Bungalow at AHOCOL Phase 1 and AHOCOL Phase 2 (AHOCOL 1 and AHOCOL 2)

\section{(i) Variable 1 - Simplicity in size of initial floor area (SSF)}

As can be seen from Figure 3, the initial floor space (area built) of the prototypes are $252.53 \mathrm{~m}^{2}$. Since they are semi-detached in nature, meaning they are meant for 2 families, the size of the dwelling unit (dwelling for one family) is $126.27 \mathrm{~m}^{2}$, which is higher than the recommended $36 \mathrm{~m}^{2}$ size in literature as a component of design simplicity of core housing schemes (Ike, 1996; Pandelaki and Shiozaki, 2010). The prototypes are rated No for this variable

\section{(ii) Variable 2 - Simplicity in shape of initial floor plan (SSP)}

The prototype has a simple geometric shape (rectangle) without pronounced projections and depressions for its floor plans as recommended in literature as a component of design simplicity of core housing schemes (Ike, 1996; Widewalls Editorial, 2017). This can be seen in Figure 4. The prototypes are rated Yes for this variable.

\section{(iii) Variable 3 - Simplicity in specification for roof covering (SSR)}

Corrugated asbestos roofing sheet is the roof covering specified for the prototype, as can be seen in 'Table 4 and Plate 2. This is one of the types recommended in literature as a component of design simplicity in architectural design of core housing schemes (Pandelaki and Shiozaki, 2010; Atamewan and Olagunju, 2017). The prototypes are rated Yes for this variable. 
Prototype 3: Detached 3- bedroom bungalow at AHOCOL Oganiru Housing Estate, Agu-Awka (AHOCOL 3)

(a) Architectural drawings

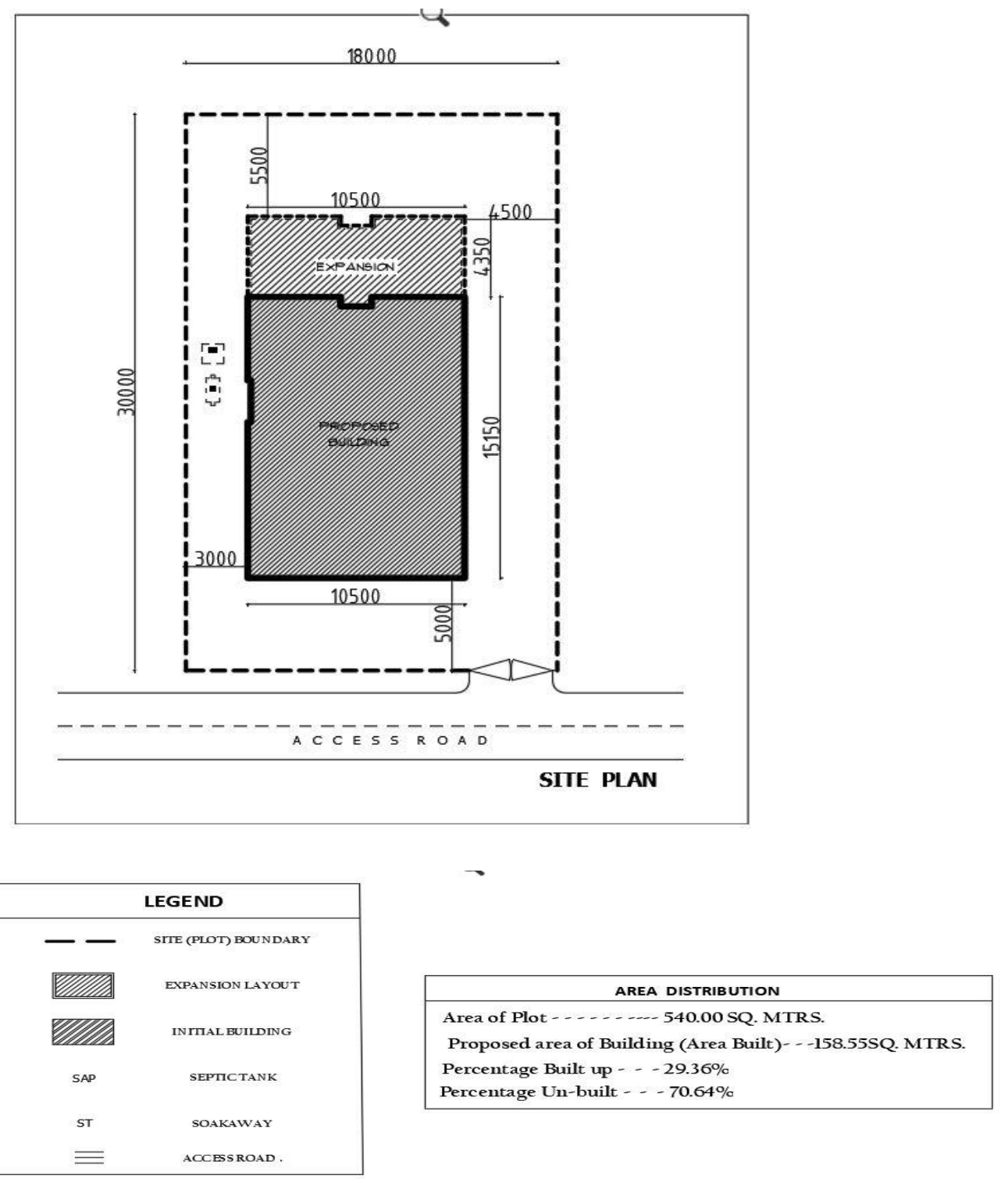

Figure 7: Site plan of the Detached 3- Bedroom Bungalow at AHOCOL Oganiru Housing Estate, Agu-Awka (AHOCOL 3)

Source: Field Work (2017). Reproduced from Archival Records of Anambra State Housing Development Corporation, Awka. 
Figure 7 is the site plan of the semi-detached 3-bedroom bungalow (core house) developed at AHOCOL Oganiru Housing Estate, Agu-Awka (AHOCOL 3). As can be seen from the Legend, the darker-shaded portion depicts the initial 3-bedroom core house, while the lightershaded portion shows the expansion layout.

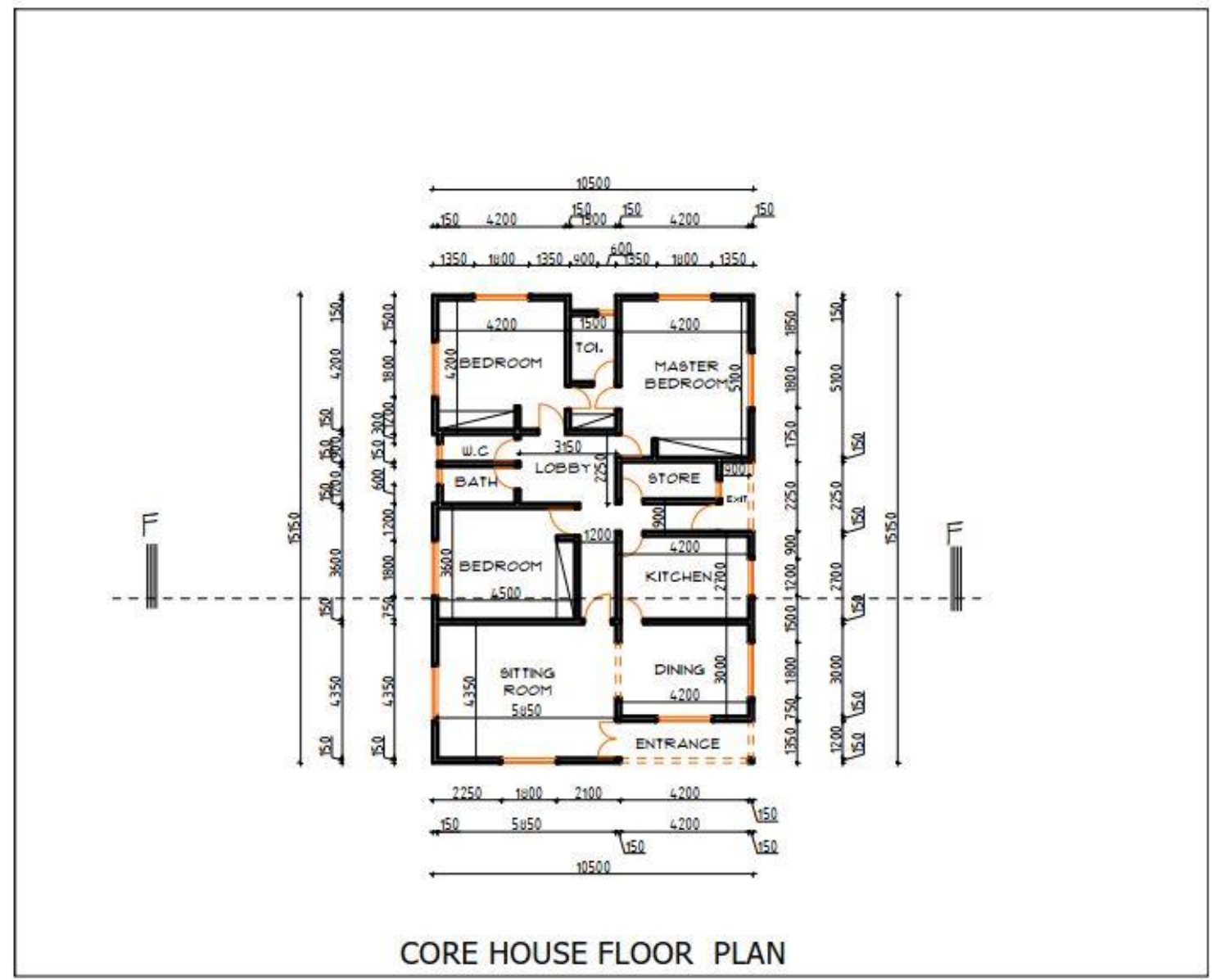

Figure 8: Floor plan of the Detached 3 -bedroom bungalow at AHOCOL Oganiru Housing Estate, Agu-Awka (AHOCOL 3)

Source: Field Work (2017). Reproduced from Archival Records of Anambra State Housing Development Corporation, Awka.

Figure 8 is the floor plan of the semi-detached 3-bedroom bungalow (core house) developed at AHOCOL Oganiru Housing Estate, Agu-Awka (AHOCOL 3). 


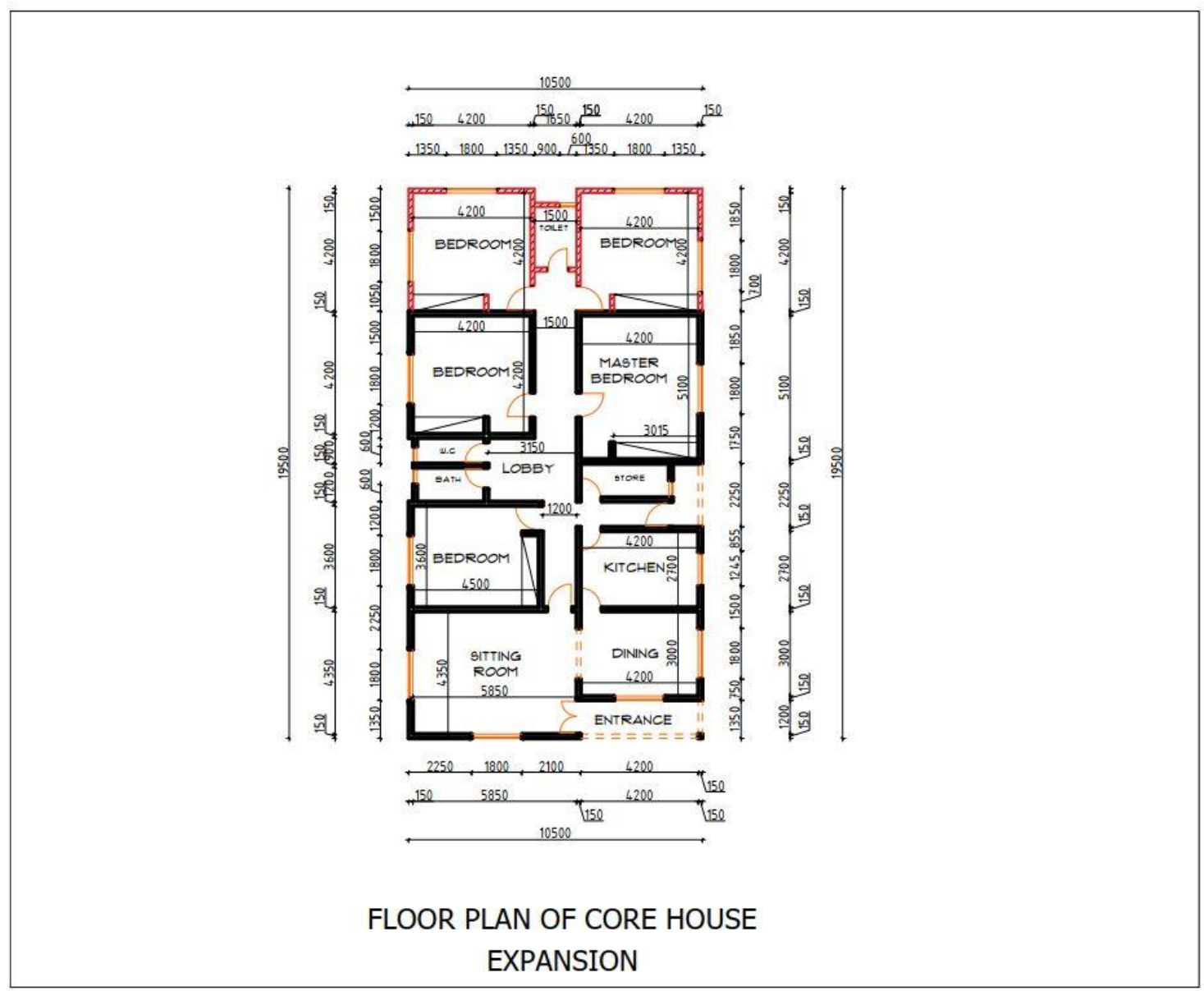

Figure 9: Floor Plan for Core House Expansion, the Detached 3 - bedroom Bungalow at AHOCOL Oganiru Housing Estate, Agu-A wka (AHOCOL 3)

Source: Field Work (2017). Reproduced from Archival Records of Anambra State Housing Development Corporation, Awka.

Figure 9 is the floor plan for core house expansion of the semi-detached 3 - bedroom bungalow (core house) developed at AHOCOL Oganiru Housing Estate, Agu-Awka (AHOCOL 3). 


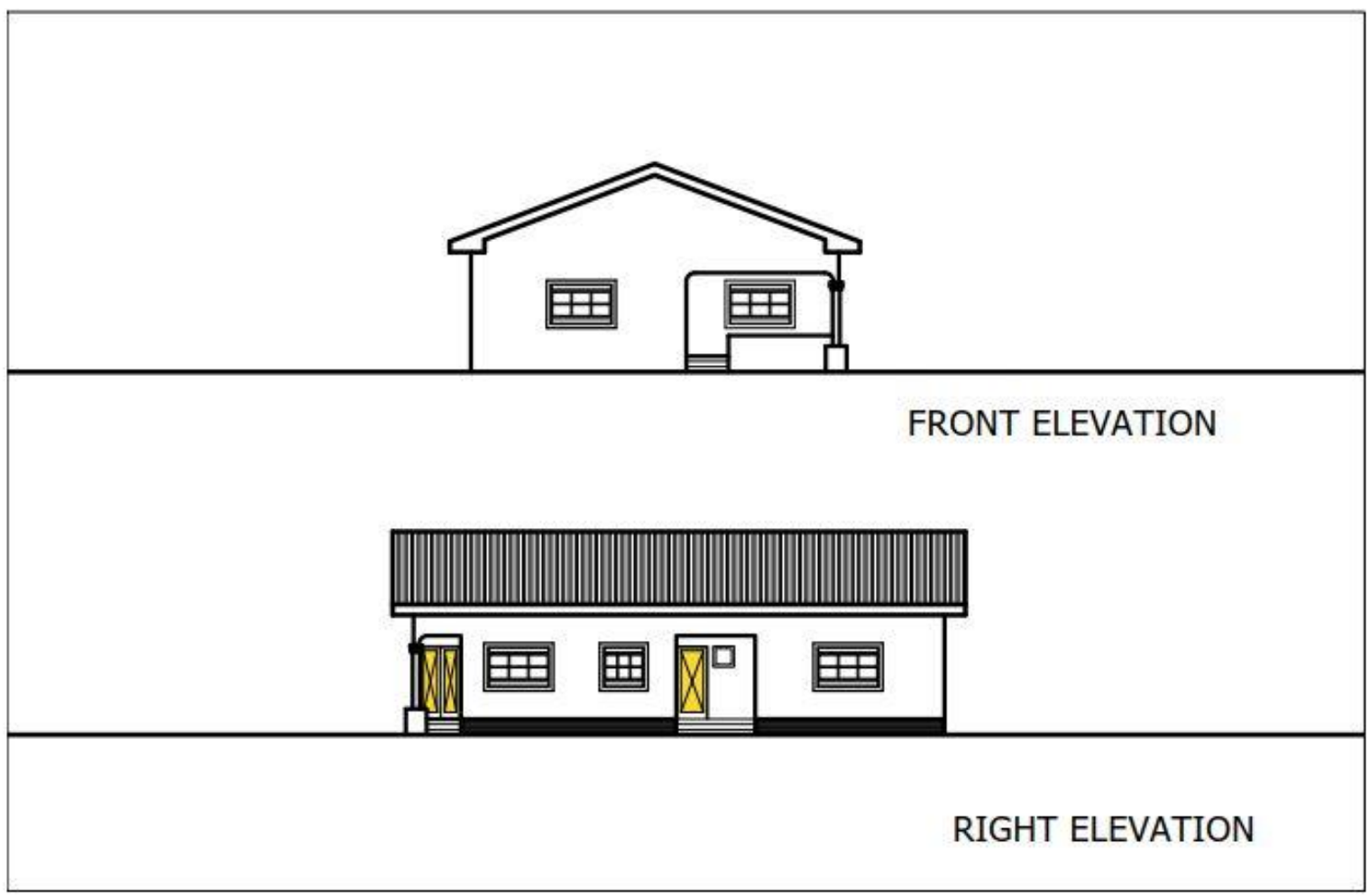

Figure 10: Front and Right Side Elevations of the Detached 3 -bedroom Bungalow at AHOCOL Oganiru Housing Estate, Agu-Awka (AHOCOL 3).

Source: Field Work (2017). Reproduced from Archival Records of Anambra State Housing Development Corporation, Awka.

Figure 10 is the front sand right side elevations of the semi-detached 3 - bedroom bungalow (core house) developed at AHOCOL Oganiru Housing Estate, Agu-Awka (AHOCOL 3). 
(b) Photographic image.

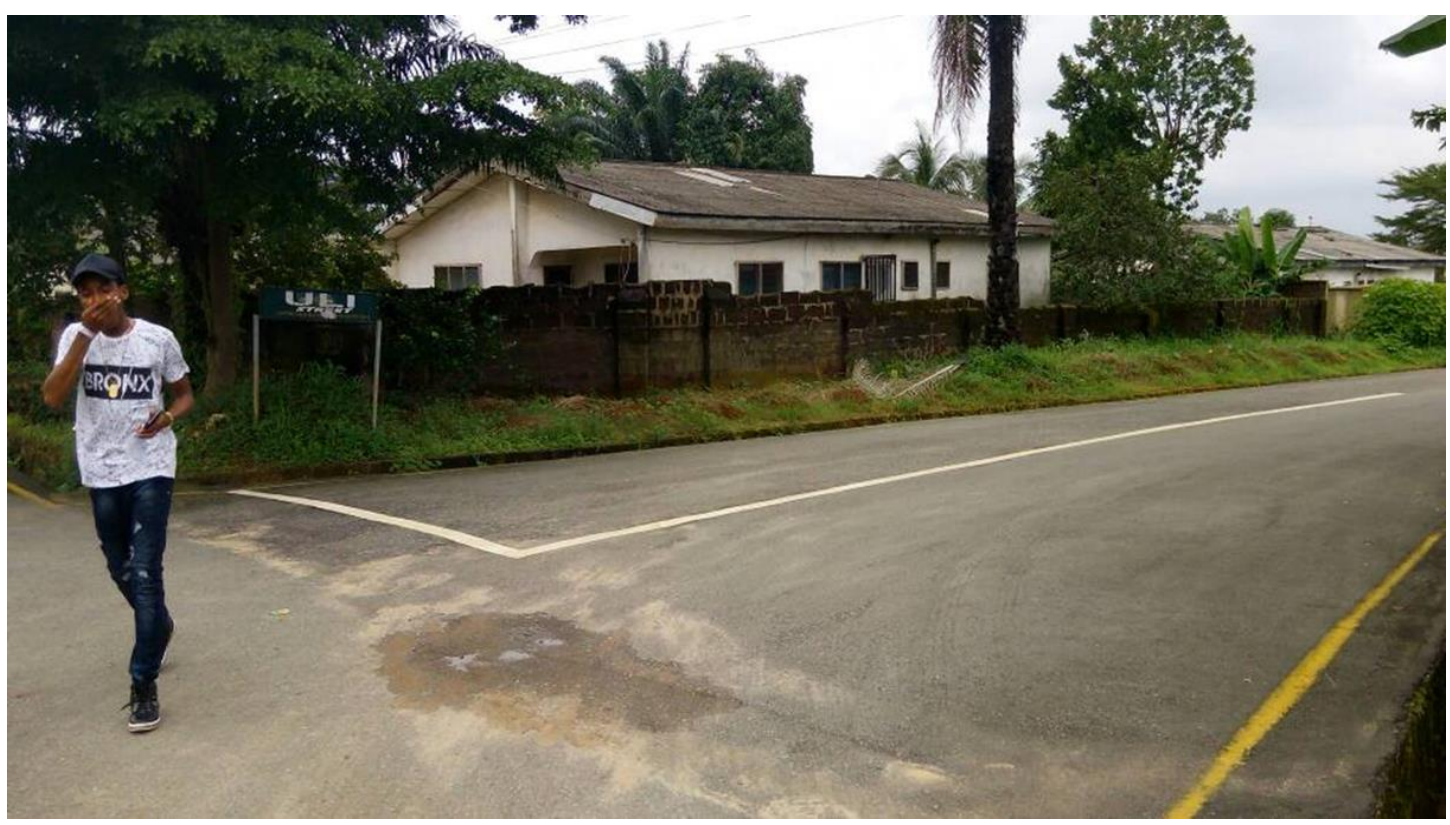

Plate 2: $\quad$ The Detached 3 - bedroom bungalow at AHOCOL Oganiru Housing Estate, Agu-Awka (AHOCOL 3) showing Cement Block Wall Material and Corrugated Asbestos Sheets as Roof Covering

(b) Building materials/finishes specification schedule.

Table 5 is the building materials/finishes specification schedule of the semi-detached 3bedroom bungalow (core house) developed at AHOCOL Oganiru Housing Estate, Agu-Awka (AHOCOL 3).

Table 5: Building Materials/Finishes Specification Schedule

\begin{tabular}{ll}
\hline Building Element & Building Material/Finish \\
\hline Wall & $150 \mathrm{~mm}$ sandcrete block \\
Roof covering & Asbestos roofing sheets \\
Floor finish & Sand/cement screed \\
\hline
\end{tabular}

Source: Fieldwork (2017). Compiled from the Architectural Drawings of Existing Core House Prototype obtained from Anambra State Housing Development Corporation, Awka and Field Observation. 
(c) Result on asertaining the characteristic "design simplicity" in architectural design of detached 3- bedroom bungalow at AHOCOL Oganiru Housing Estate, AguAwka (AHOCOL 3)

\section{(i) Variable 1 - Simplicity in size of initial floor area (SSF)}

As can be seen from Figure 7, the initial floor space (area built) of the prototype is $158.55 \mathrm{~m}^{2}$, which is the size of the dwelling unit (dwelling for one family) as the prototype is a detached housetype, meaning that it is meant for one household only. This is higher than the recommended $36 \mathrm{~m}^{2}$ size in literature as a component of design simplicity in architectural design of core housing schemes (Ike, 1996; Pandelaki and Shiozaki, 2010). The prototype is rated No for this variable.

\section{(ii) Variable 2 - Simplicity in shape of initial floor plan (SSP)}

The prototype has a simple geometric shape (rectangle) without pronounced projections and depressions for its floor plan as recommended in literature as a component of design simplicity in architectural design of core housing schemes (Ike, 1996; Widewalls Editorial, 2017). This can be seen in Figure 8. The prototype is rated Yes for this variable.

\section{(iii) Variable 3 - Simplicity in specification for roof covering (SSR)}

Corrugated asbestos roofing sheet is the roof covering of the prototype, as can be seen in Table 5 and Plate 2. This is one of the types recommended in literature as a component of design simplicity in architectural design of core housing schemes (Pandelaki and Shiozaki, 2010; Atamewan and Olagunju, 2017). The prototype is rated Yes for this variable. 
Prototype 4: Detached 2- Bedroom bungalow at AHOCOL Inner City Layout, Nkwelle, Awka (AHOCOL 4)

(a) Architectural drawings

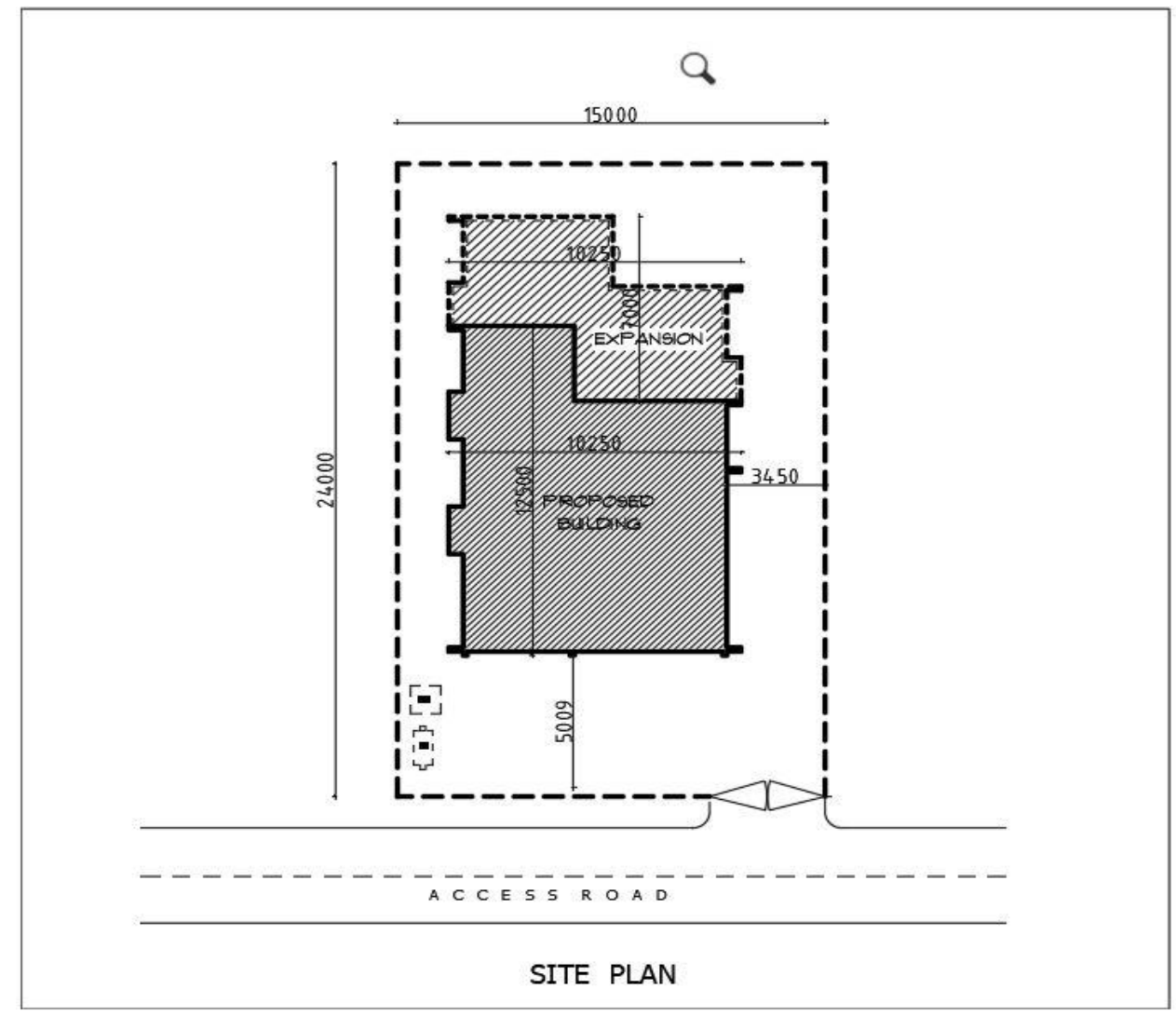

\begin{tabular}{|c|c|}
\hline \multicolumn{2}{|c|}{ LEGEND } \\
\hline-1 & STTE (PLOT) BOUNDARY \\
\hline & EXPANSION LAYOUT \\
\hline OAlna & INITLAL BUILDING \\
\hline SAP & SEPTICTANK \\
\hline ST & SOAKAWAY \\
\hline $\bar{\equiv}$ & ACCESS ROAD. \\
\hline
\end{tabular}

Figure 11: Site Plan of the Detached 2-bedroom bungalow (Core House) at AHOCOL Inner City Layout, Nkwelle, Awka (AHOCOL 4) 
Figure 11 is the site plan of the Detached 2-bedroom bungalow (core house) at AHOCOL Inner City Layout, Nkwelle, Awaka (AHOCOL 4). As can be seen from the Legend, the darker-shaded portion depicts the initial 2-bedroom core house, while the lighter-shaded portion shows the expansion layout.

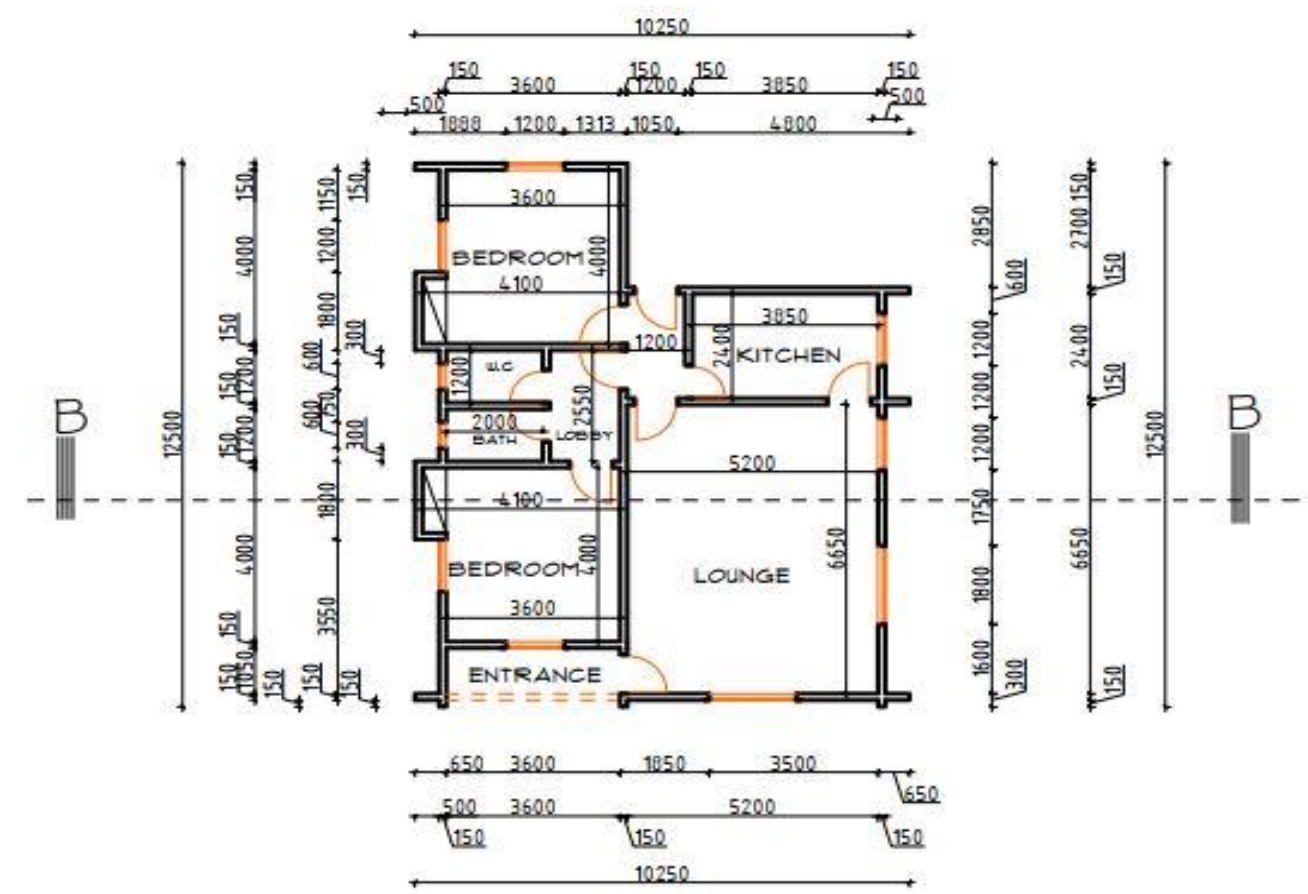

CORE HOUSE FLOOR PLAN

Figure 12: Floor Plan of the Detached 2- bedroom bungalow (Core House) at AHOCOL Inner City Layout, Nkwelle, Awka (AHOCOL 4)

Source: Field Work (2017). Reproduced from Archival Records of Anambra State Housing Development Corporation, Awka.

Figure 12 is the floor plan of the Detached 2- bedroom bungalow (Core house) at AHOCOL Inner City Layout, Nkwelle, Awka (AHOCOL 4). 


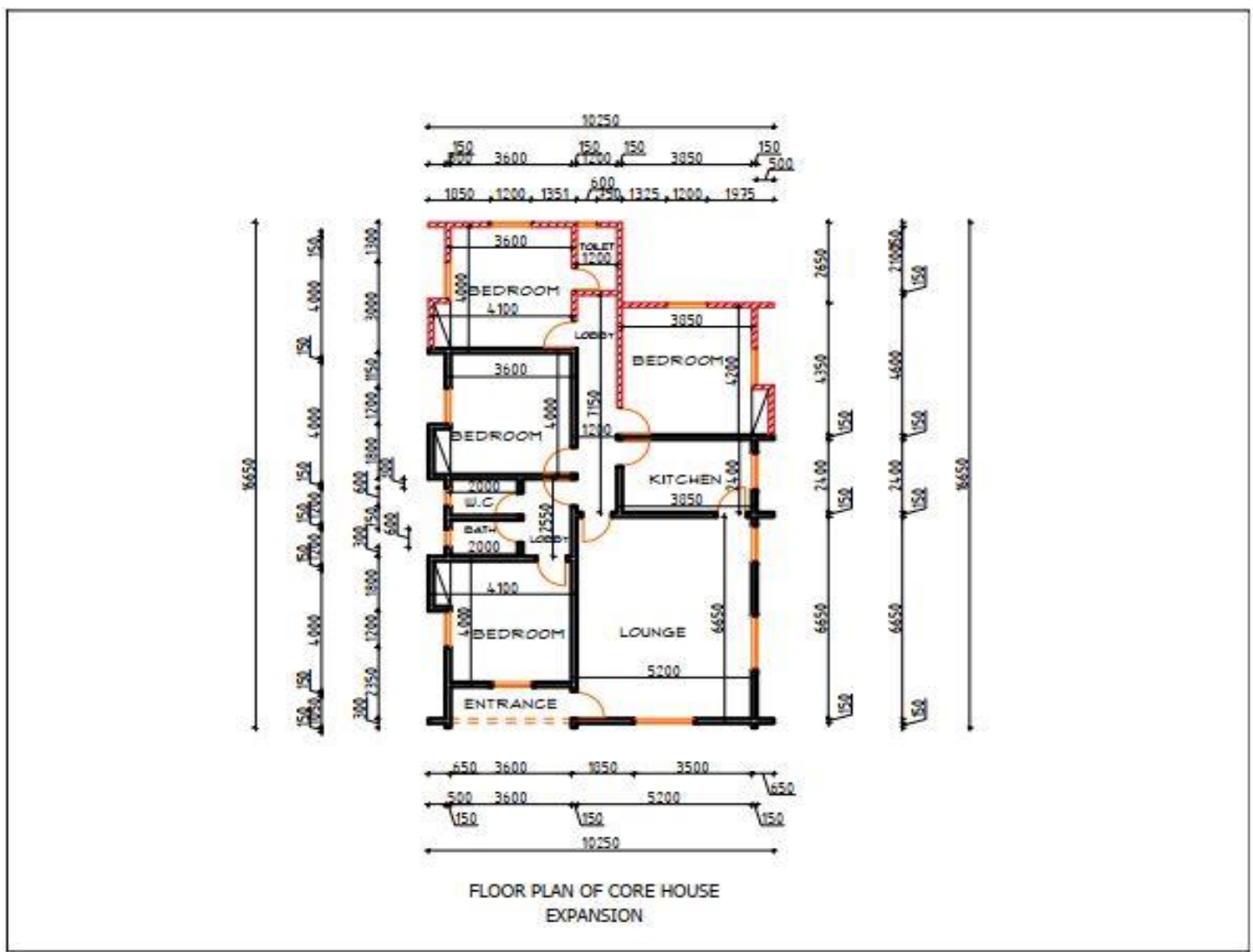

Figure 13: Floor plan for Core House Expansion, the Detached 2- bedroom bungalow (Core House) at AHOCOL Inner City Layout, Nkwelle, Awka (AHOCOL 4)

Source: Field Work (2017). Reproduced from Archival Records of Anambra State Housing Development Corporation, Awka.

Figure 13 is the floor plan for core house expansion of the Detached 2- bedroom bungalow (Core house) at AHOCOL Inner City Layout, Nkwelle, Awka (AHOCOL 4). 


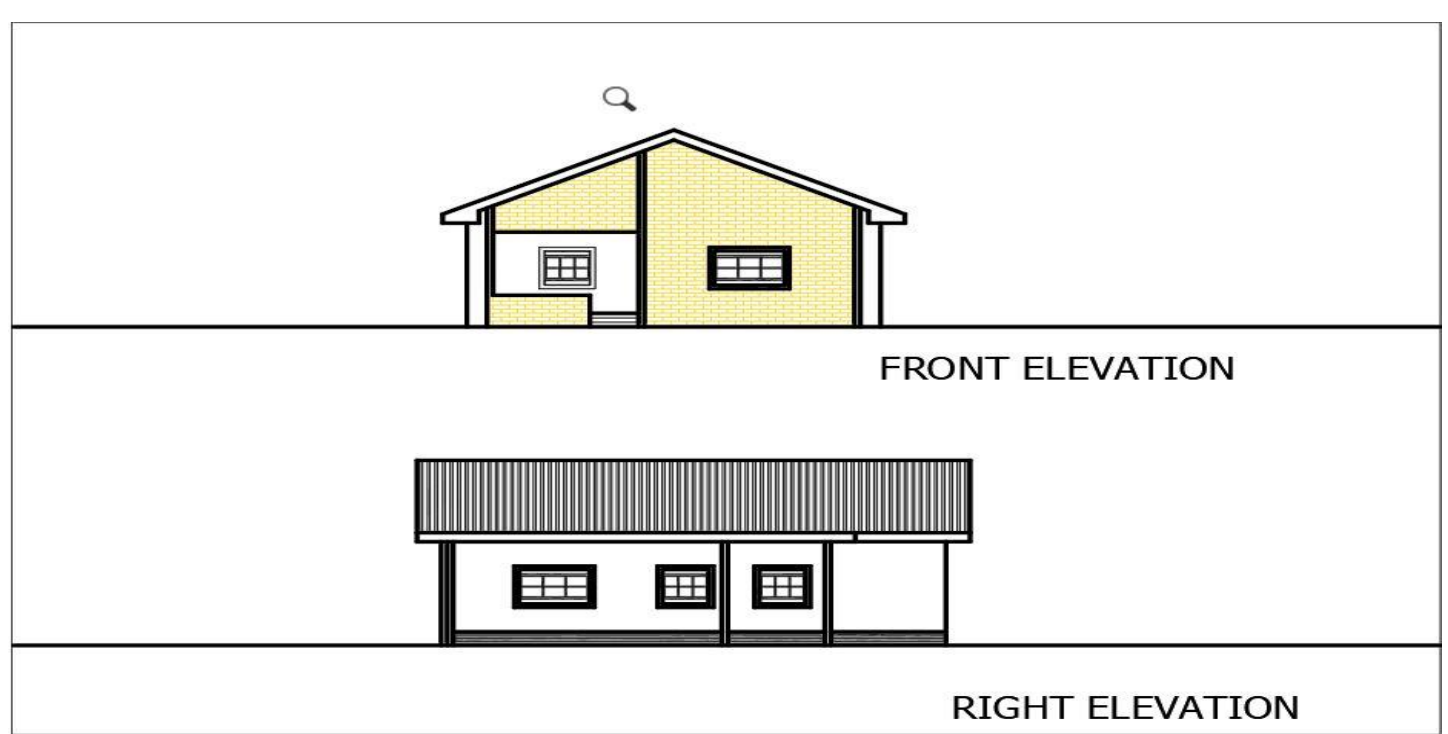

Figure 14: Front and Right Side Elevations of the Detached 2- bedroom bungalow (Core House) at AHOCOL Inner City Layout, Nkwelle, Awka (AHOCOL 4)

Figure 14 is the front and right side elevations of the Detached 2- bedroom bungalow (Core house) at AHOCOL Inner City Layout, Nkwelle, Awka (AHOCOL 4).

(b) Photographic image.

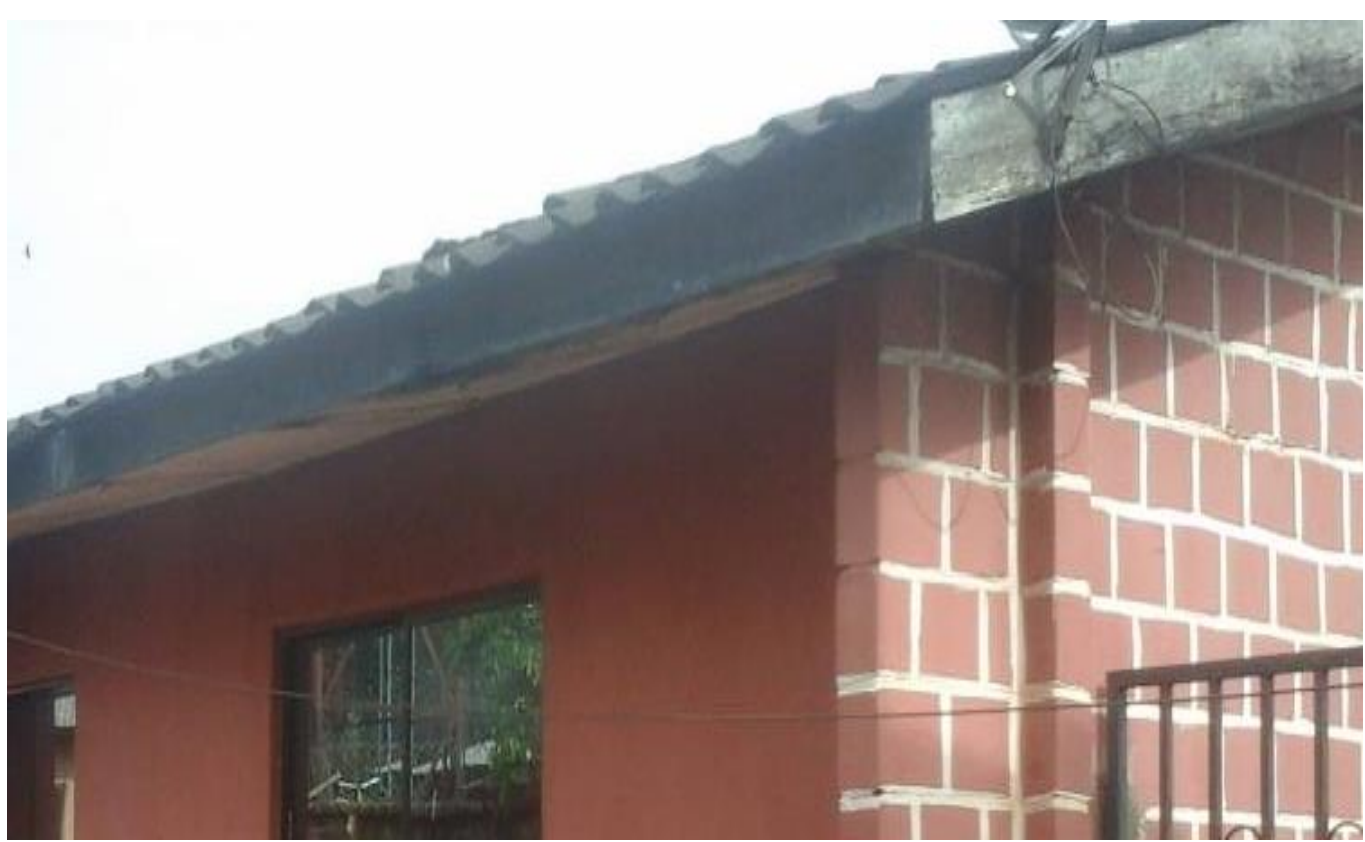

Plate 6: Detached 2- bedroom bungalow (Core House) at AHOCOL Inner City Layout, Nkwelle, Awka (AHOCOL 4) showing Cement Block Wall Material, Oven-baked brick for Front Wall and Clay tiles as Roof Covering 


\section{(c)Building Materials/Finishes Specification Schedule}

Table 6 is the building materials/finishes specification schedule of the 2- bedroom bungalow (Core House) at AHOCOL Inner City Layout, Nkwelle, Awka (AHOCOL 4).

Table 6: Building Materials/Finishes Specification Schedule

\begin{tabular}{lc}
\hline Building Element & Building Material/Finish \\
\hline Wall & $150 \mathrm{~mm}$ sandcrete block, $100 \mathrm{~mm}$ oven- baked \\
Roof covering & brick for front wall \\
Floor finish & Clay tile \\
& Sand/cement screed \\
\hline
\end{tabular}

Source: Fieldwork (2017). Compiled from the Architectural Drawings of Existing Core House Prototype obtained from Anambra State Housing Development Corporation, Awka and Field Observation.

(c) Result on asertaining the characteristic "flexibility in space use in architectural design" in the detached 2- bedroom bungalow at AHOCOL Inner City Layout, Nkwelle, Awka (AHOCOL 4)

(i) Variable 1 - Simplicity in size of initial floor area (SSF)

As can be seen from Figure 11, the initial floor space (area built) of the prototype is 128.13 $\mathrm{m}^{2}$, which is the size of the dwelling unit (dwelling for one family) as the prototype is a detached housetype, meaning that it is meant for one household only. This is higher than the $36 \mathrm{~m}^{2}$ mark for size of a simple core house. The prototype is rated No for this variable

(ii) Variable 2 - Simplicity in shape of initial floor plan (SSP)

The prototype has a simple geometric shape (rectangle) without pronounced projections and depressions for its floor plan. This can be seen in Figure 12. The prototype is rated Yes for this variable.

\section{(iii) Variable 3 - Simplicity in specification for roof covering (SSR)}

Clay tile is the roof covering of the prototype, as can be seen in Table 6 and Plates 6 , This is one of the types recommended in literature as a component of design simplicity in architectural design of core housing schemes (Pandelaki and Shiozaki, 2010; Atamewan and Olagunju, 207). The prototype is rated Yes for this variable. 
Prototype 5: Detached 1 - Bedroom bungalow (core house) at ASHDC Ngozika Housing Estate, Phase 1, Ikwodiaku, Awka (NGOZIKA 1)

(a) Architectural drawings
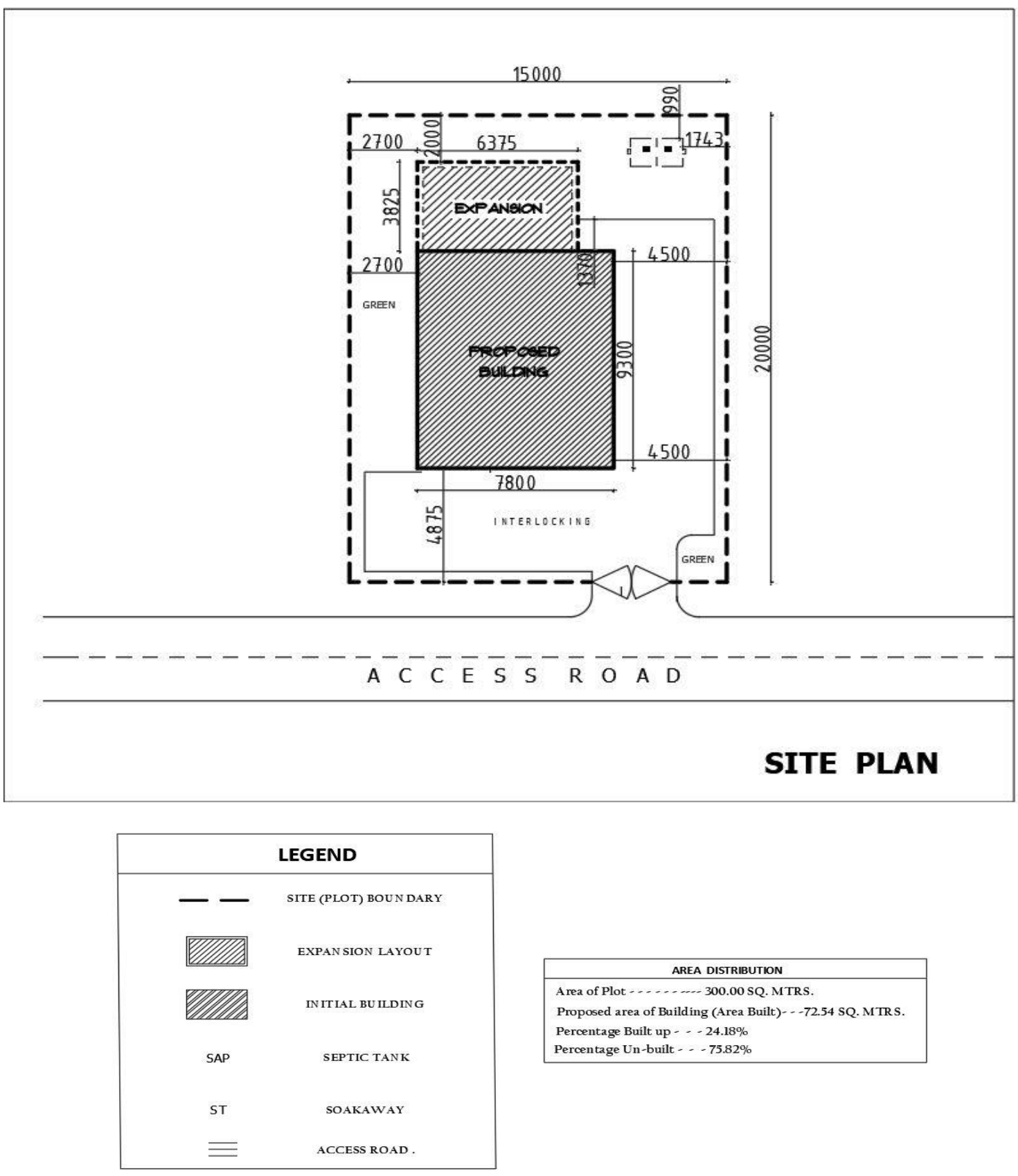

Fig. 15: Site Plan of the Detached 1- bedroom Bungalow (Core House) at ASHDC Ngozika Housing Estate, Phase 1, Ikwodiaku, Awka (NGOZIKA 1)

Source: Field Work (2017). Reproduced from Archival Records of Anambra State Housing Development Corporation, Awka. 
Figure 15 is the site plan of the Detached 1- bedroom Bungalow (Core House) at ASHDC Ngozika Housing Estate, Phase 1, Ikwodiaku, Awka (NGOZIKA 1)

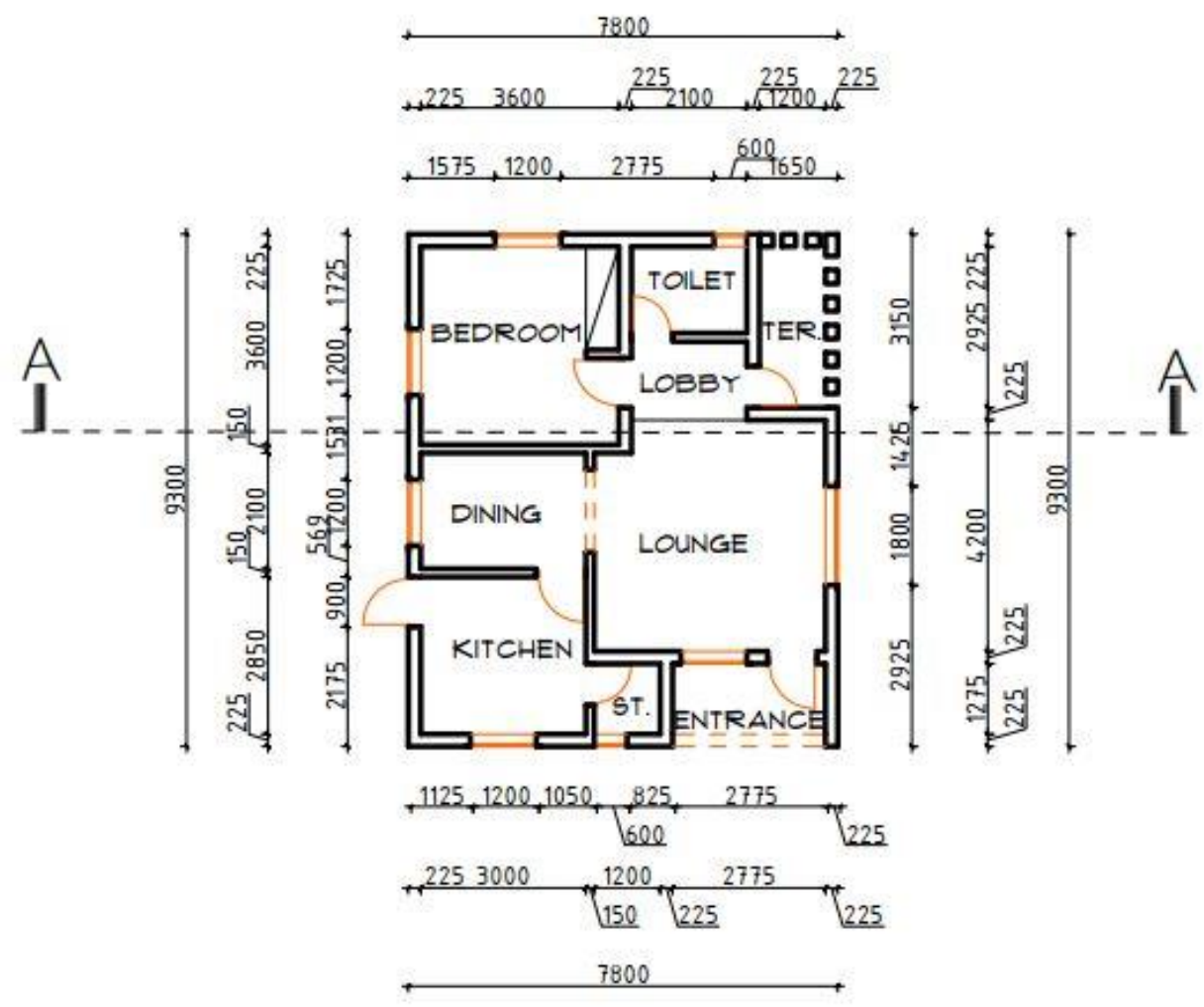

CORE HOUSE FLOOR PLAN

Figure 16: Floor Plan of the Detached 1- bedroom bungalow (Core House) at ASHDC Ngozika Housing Estate, Phase 1, Ikwodiaku, Awka (NGOZIKA 1)

Source: Field Work (2017). Reproduced from Archival Records of Anambra State Housing Development Corporation, Awka.

Figure 16 is the floor plan of the Detached 1- bedroom bungalow (Core House) at ASHDC Ngozika Housing Estate, Phase 1, Ikwodiaku, Awka (NGOZIKA 1). 


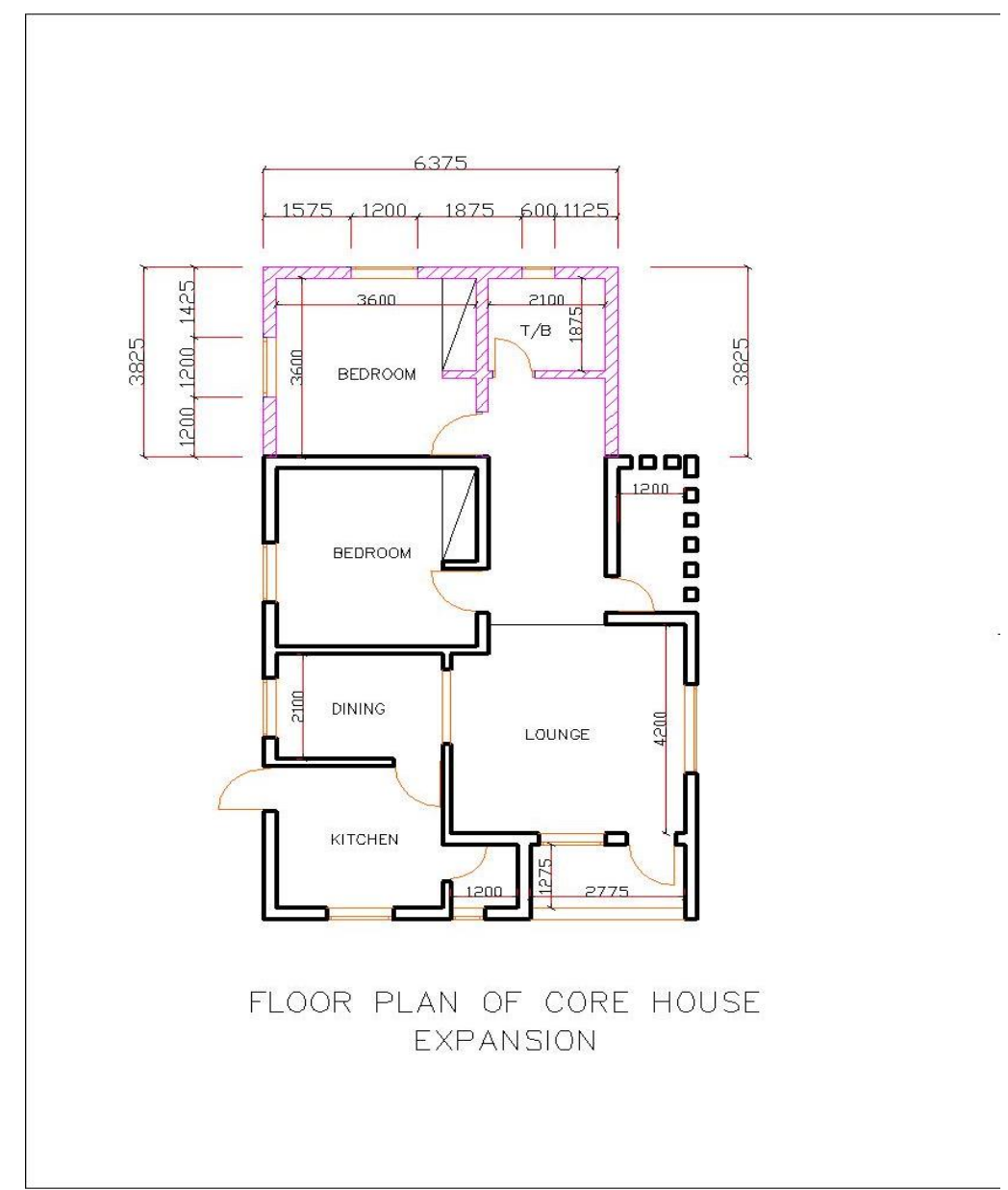

Figure 17: Floor Plan for Core House Expansion, the Detached 1- bedroom bungalow (Core House) at ASHDC Ngozika Housing Estate, Phase 1, Ikwodiaku, Awka (NGOZIKA 1)

Source: Field Work (2017). Reproduced from Archival Records of Anambra State Housing Development Corporation, Awka.

Figure 17 is the floor plan for Core House expansion of the Detached 1- bedroom bungalow (Core House) at ASHDC Ngozika Housing Estate, Phase 1, Ikwodiaku, Awka (NGOZIKA 1). 


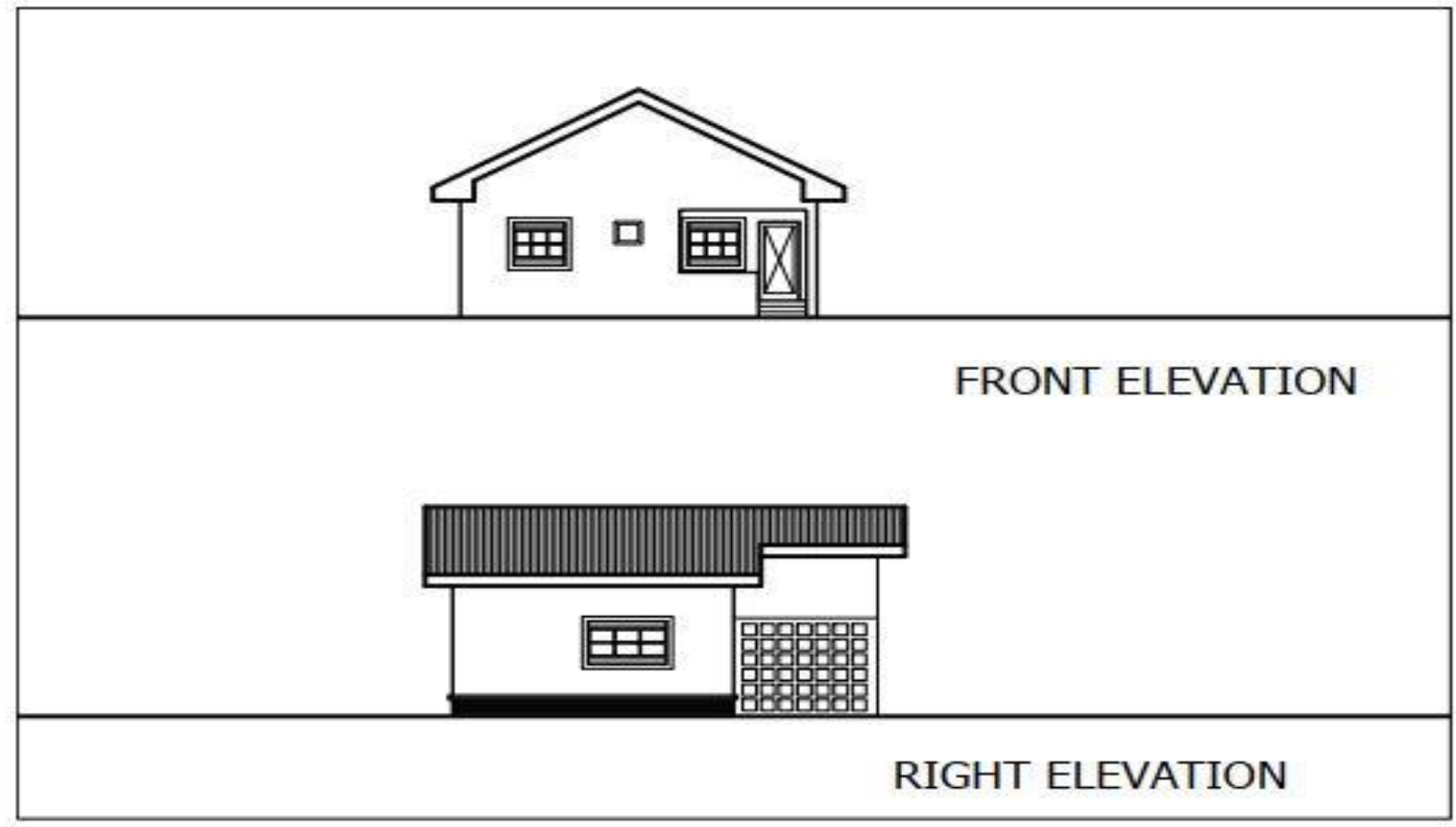

Figure 18: Front and Right Side Elevations of the Detached 1- bedroom bungalow (Core House) at ASHDC Ngozika Housing Estate, Phase 1, Ikwodiaku, Awka (NGOZIKA 1)

Source: Field Work (2017). Reproduced from Archival Records of Anambra State Housing Development Corporation, Awka.

Figure 18 is the front and right side elevations of the Detached 1- bedroom bungalow (Core House) at ASHDC Ngozika Housing Estate, Phase 1, Ikwodiaku, Awka (NGOZIKA 1). 
(b) Photographic image

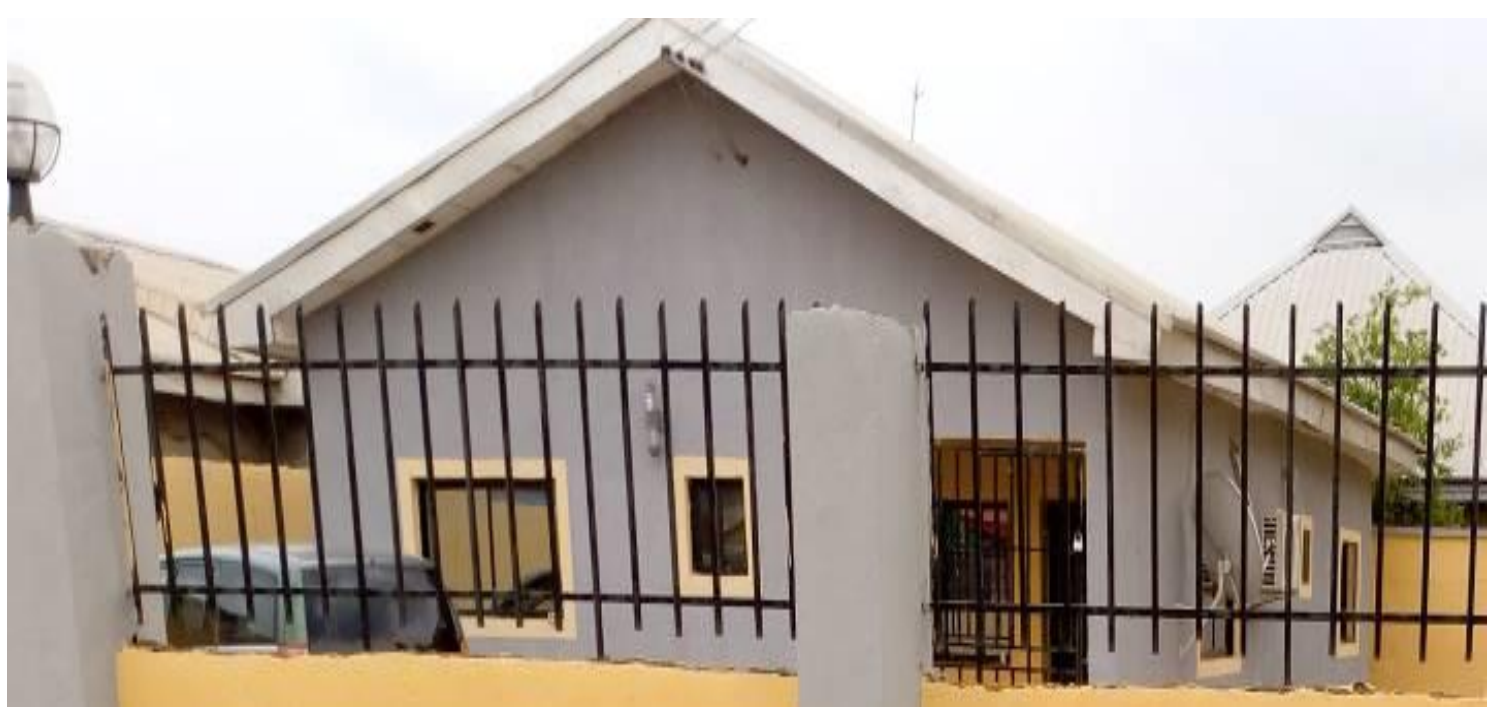

Plate 7: Detached 1- bedroom bungalow (Core House) at ASHDC Ngozika Housing Estate, Phase 1, Ikwodiaku, Awka (NGOZIKA 1) showing Cement Block Wall Material and Longspan Aluminum as Roof Covering.

(c) Building materials/finishes specification schedule

Table 7 is the building materials/finishes specification schedule of the Detached 1- bedroom bungalow (Core House) at ASHDC Ngozika Housing Estate, Phase 1, Ikwodiaku, Awka (NGOZIKA 1)

Table 7: Building Materials/Finishes Specification Schedule

\begin{tabular}{ll}
\hline Building Element & Building Material/Finish \\
\hline Wall & $150 \mathrm{~mm}$ sandcrete block \\
Roof covering & $.45 \mathrm{~mm}$ longspan aluminium roofing sheets \\
Floor finish & Sand/cement screed \\
\hline
\end{tabular}

Source: Fieldwork (2017). Compiled from the Architectural Drawings of Existing Core House Prototype obtained from Anambra State Housing Development Corporation, Awka and Field Observation. 
(c) Result on asertaining the attribute "design simplicity" in architectural design" of the Detached 1- bedroom bungalow at ASHDC Ngozika Housing Estate, Phase 1, Ikwodiaku, Awka (NGOZIKA 1)

\section{(i) Variable 1 - Simplicity in size of initial floor area (SSF)}

As can be seen from Figure 15, the initial floor space (area built) of the prototype is $72.54 \mathrm{~m}^{2}$, which is the size of the dwelling unit (dwelling for one family) as the prototype is a detached housetype, meaning that it is meant for one household only. This is higher than the recommended $36 \mathrm{~m}^{2}$ size in literature as a component of design simplicity in architectural design of core housing schemes (Ike, 1996; Pandelaki and Shiozaki, 2010). The prototype is rated No for this variable.

\section{(ii) Variable 2 - Simplicity in shape of initial floor plan (SSP)}

The prototype has a simple geometric shape (rectangle) without pronounced projections and depressions for its floor plan plan as recommended in literature as a component of design simplicity in architectural design of core housing schemes (Ike, 1996; Widewalls Editorial, 2017). This can be seen in Figure 16. The prototype is rated Yes for this variable.

\section{(iii) Variable 3 - Simplicity in specification for roof covering (SSR)}

Longspan aluminum roofing sheet is the roof covering of the prototype, as can be seen in Table 7 and Plate 7, rather than corrugated asbestos roofing sheet or clay tile types recommended in literature as a component of design simplicity in architectural design of core housing schemes (Pandelaki and Shiozaki, 2010; Atamewan and Olagunju, 2017). The prototype is rated No for this variable. 
Prototype 6: Detached 2- bedroom bungalow at ASHDC Ngozika Housing Estate, Phase 1, Ikwodiaku, Awka (NGOZIKA 2)

(a) Architectural drawings

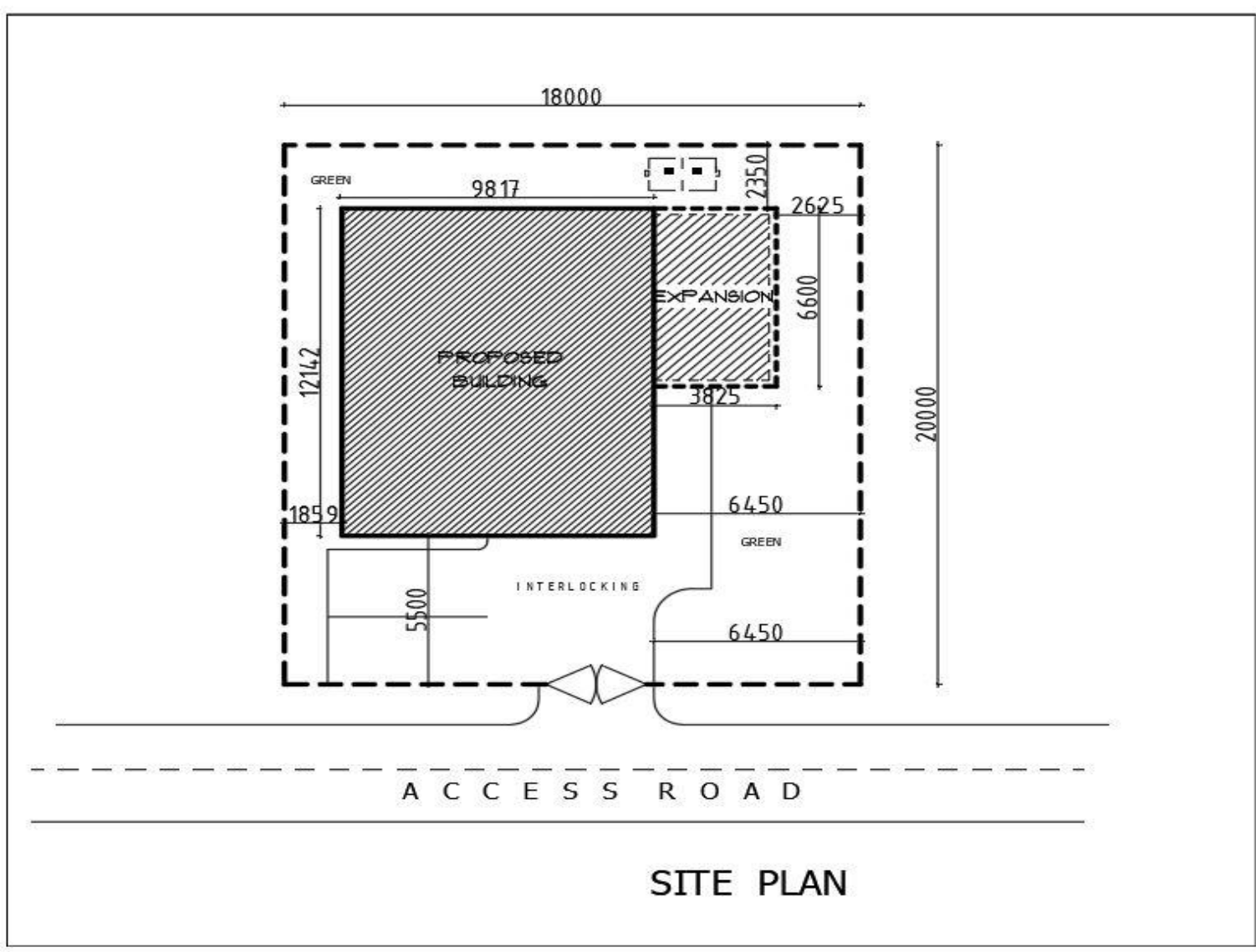

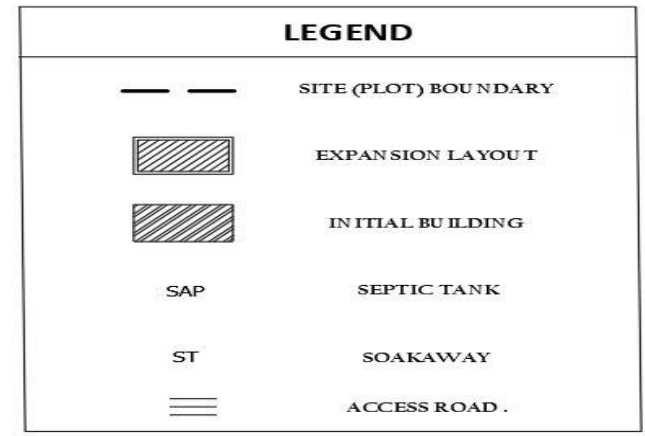

\begin{tabular}{|c|}
\hline AREA DISTRIBUTION \\
\hline $\begin{array}{l}\text { Area of Plot } \ldots \ldots \ldots \ldots \text {..... } 360.00 \text { SQ. MTRS. } \\
\text { Proposed area of Building (Area Built) - -118.47 SQ. MTRS. }\end{array}$ \\
\hline $\begin{array}{l}\text { Percentage Built up } \ldots-32.98 \% \\
\text { Percentage Un-built } \ldots-67.02 \%\end{array}$ \\
\hline
\end{tabular}

Figure 19: Site Plan of the Detached 2- bedroom bungalow (Core House) at ASHDC Ngozika Housing Estate, Phase 1, Ikwodiaku, Awka (NGOZIKA 1)

Source: Field Work (2017). Reproduced from Archival Records of Anambra State Housing Development Corporation, Awka. 
Figure 19 is the site plan of the Detached 2 - bedroom bungalow (Core House) at ASHDC Ngozika Housing Estate, Phase 1, Ikwodiaku, Awka (NGOZIKA 1) as can be seen from the Legend, the darker-shaded portion depicts the initial 2-bedroom core house, while the lightershaded portion shows the expansion layout.

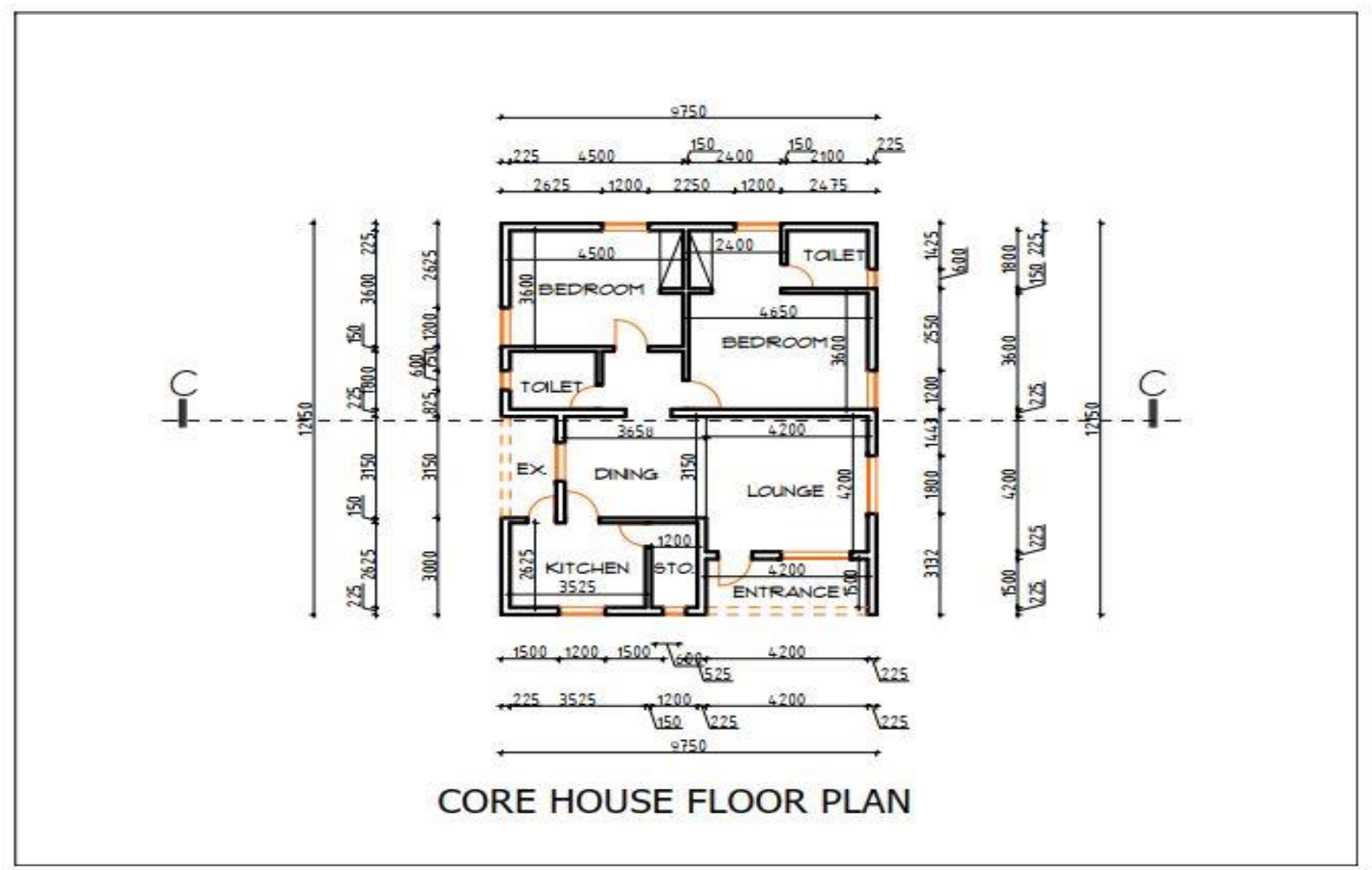

Figure 20: Floor Plan of the Detached 2- bedroom Bungalow (Core House) at ASHDC Ngozika Housing Estate, Phase 1, Ikwodiaku, Awka (NGOZIKA 1)

Source: Field Work (2017). Reproduced from Archival Records of Anambra State Housing Development Corporation, Awka.

Figure 20 is the floor plan of the Detached 2-bedroom bungalow (Core House) at ASHDC Ngozika Housing Estate, Phase 1, Ikwodiaku, Awka (NGOZIKA 1). 


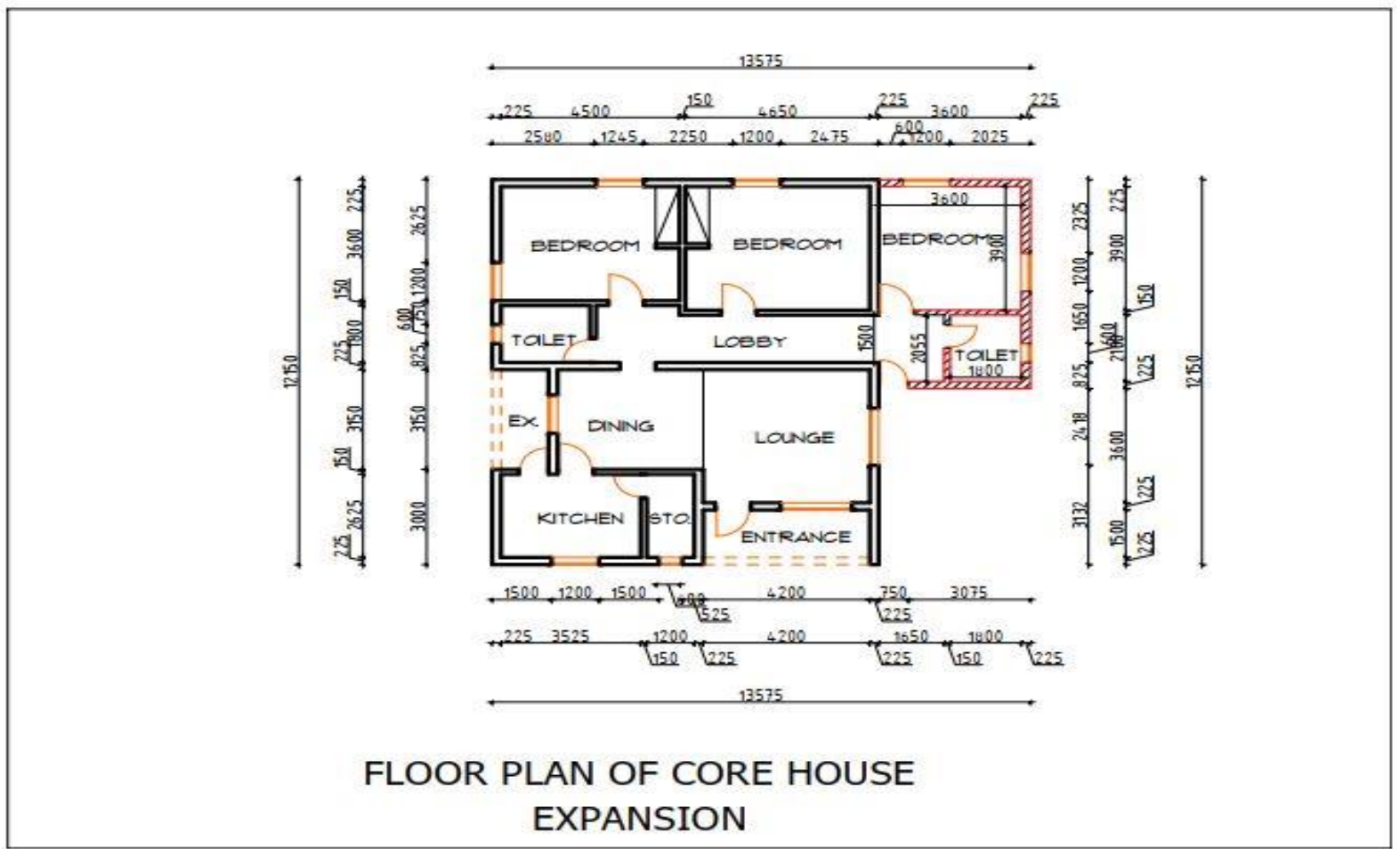

Figure 21: Floor plan for Core House Expansion, the Detached 2- bedroom bungalow (Core House) at ASHDC Ngozika Housing Estate, Phase 1, Ikwodiaku, Awka (NGOZIKA 1)

Source: Field Work (2017). Reproduced from Archival Records of Anambra State Housing Development Corporation, Awka.

Figure 21 is the floor plan for Core House Expansion of the Detached 2- bedroom bungalow (Core House) at ASHDC Ngozika Housing Estate, Phase 1, Ikwodiaku, Awka (NGOZIKA 1). 
(b) Photographic image

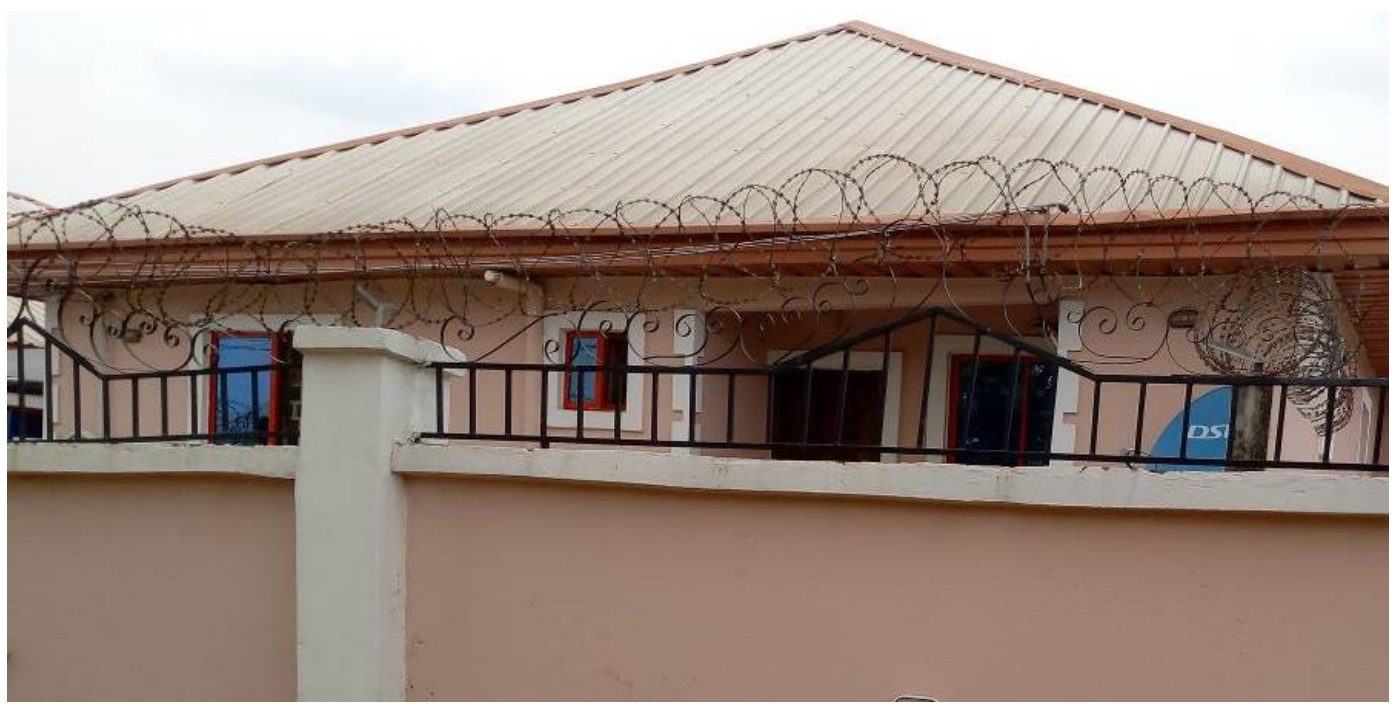

Plate 8: Detached 2- bedroom bungalow (Core House) at ASHDC Ngozika Housing Estate, Phase 1, Ikwodiaku, Awka (NGOZIKA 1) showing its appearance as a full-provision house rather than a partial-provision type (core house).

(c) Building materials/finishes specification schedule

Table 8 is the building materials/finishes specification schedule of the Detached 2- bedroom bungalow (Core House) at ASHDC Ngozika Housing Estate, Phase 1, Ikwodiaku, Awka (NGOZIKA 1).

Table 8: Building Materials/Finishes Specification Schedule

\begin{tabular}{ll}
\hline Building Element & Building Material/Finish \\
\hline Wall & $150 \mathrm{~mm}$ sandcrete block \\
Roof covering & $.45 \mathrm{~mm}$ longspan aluminium roofing sheets \\
Floor finish & Ceramic tiles \\
\hline
\end{tabular}

Source: Fieldwork (2017). Compiled from the Architectural Drawings of Existing Core House Prototype obtained from Anambra State Housing Development Corporation, Awka and Field Observation. 
(c) Result on asertaining the attribute "design simplicity" in architectural design" of the Detached 2- bedroom bungalow at ASHDC Ngozika Housing Estate, Phase 1, Ikwodiaku, Awka (NGOZIKA 2)

\section{(i) Variable 1 - Simplicity in size of initial floor area (SSF)}

As can be seen from Figure 19, the initial floor space (area built) of the prototype is 128.12 $\mathrm{m}^{2}$, which is the size of the dwelling unit (dwelling for one family) as the prototype is a detached housetype, meaning that it is meant for one household only. This is higher than the recommended $36 \mathrm{~m}^{2}$ size in literature as a component of design simplicity in architectural design of core housing schemes (Ike, 1996; Pandelaki and Shiozaki, 2010). The prototype is rated No for this variable.

\section{ii) Variable 2 - Simplicity in shape of initial floor plan (SSP)}

The prototype has a simple geometric shape (rectangle) without pronounced projections and depressions for its floor plan as recommended in literature as a component of design simplicity in architectural design of core housing schemes (Ike, 1996; Widewalls Editorial, 2017). This can be seen in Figure 20. The prototype is rated Yes for this variable.

\section{(iii) Variable 3 - Simplicity in specification for roof covering (SSR)}

Longspan aluminum roofing sheet is the roof covering of the prototype, as can be seen in Table 8 and Plate 8 , rather than corrugated asbestos roofing sheet or clay tile types recommended in literature as a component of design simplicity in architectural design of core housing schemes (Pandelaki and Shiozaki, 2010; Atamewan and Olagunju, 2017). The prototype is rated No for this variable. 
Prototype 7: Detached 3- bedroom bungalow at ASHDC Ngozika Housing Estate, Phase 1, Ikwodiaku, Awka (NGOZIKA 3)

(a) Architectural drawing
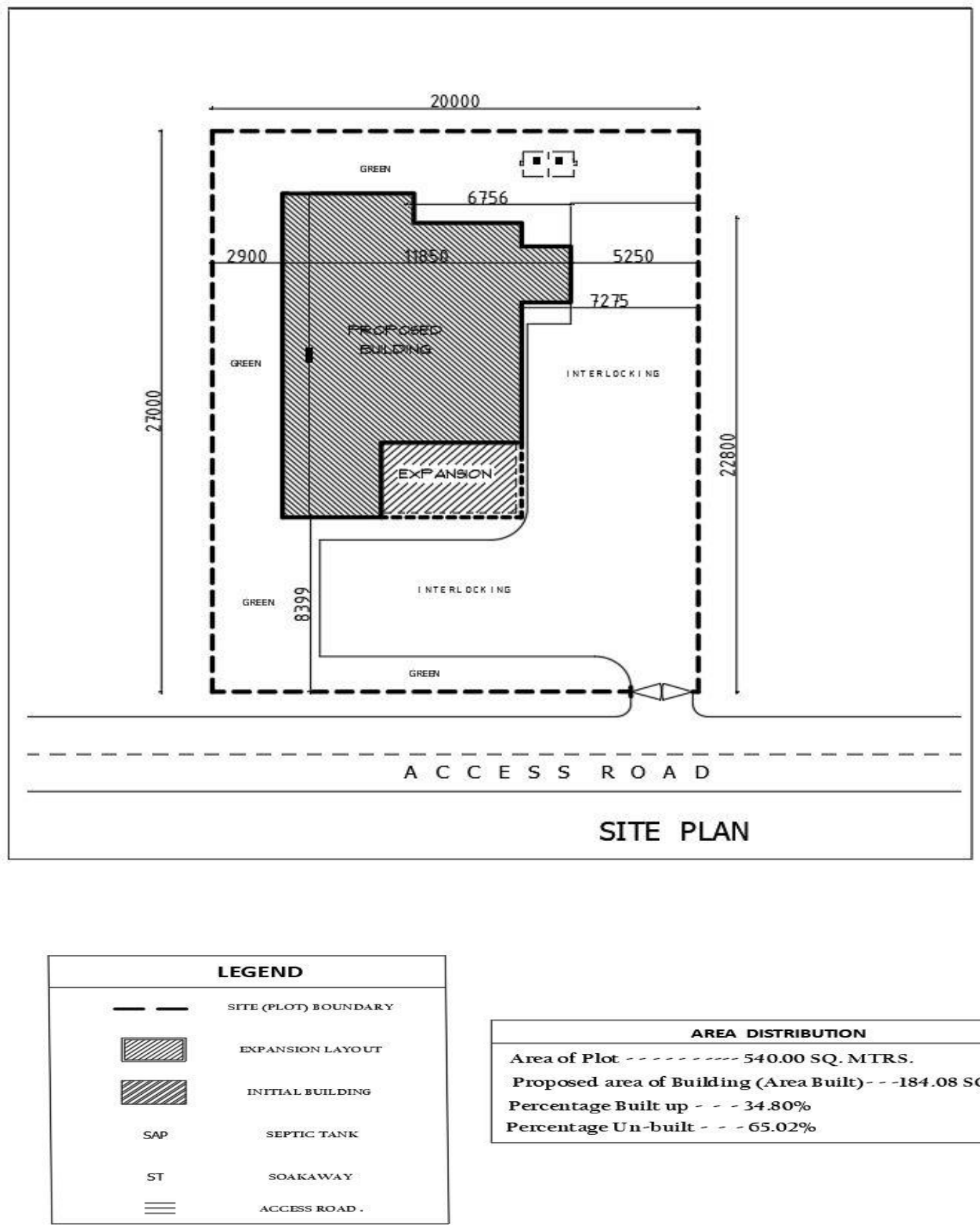

\begin{tabular}{|l|}
\hline AREA DISTRIBUTION \\
\hline Area of Plot $\ldots \ldots \ldots \ldots$ \\
Proposed area of Building (Area Built) $\ldots-184.08$ SQ. MTRS. \\
Percentage Built up $\ldots-34.80 \%$ \\
Percentage Un-built $\ldots-65.02 \%$ \\
\hline
\end{tabular}

Figure 22: Site Plan of the Detached 2- bedroom bungalow (Core House) at ASHDC Ngozika Housing Estate, Phase 1, Ikwodiaku, Awka (NGOZIKA 3)

Source: Field Work (2017). Reproduced from Archival Records of Anambra State Housing Development Corporation, Awka. 


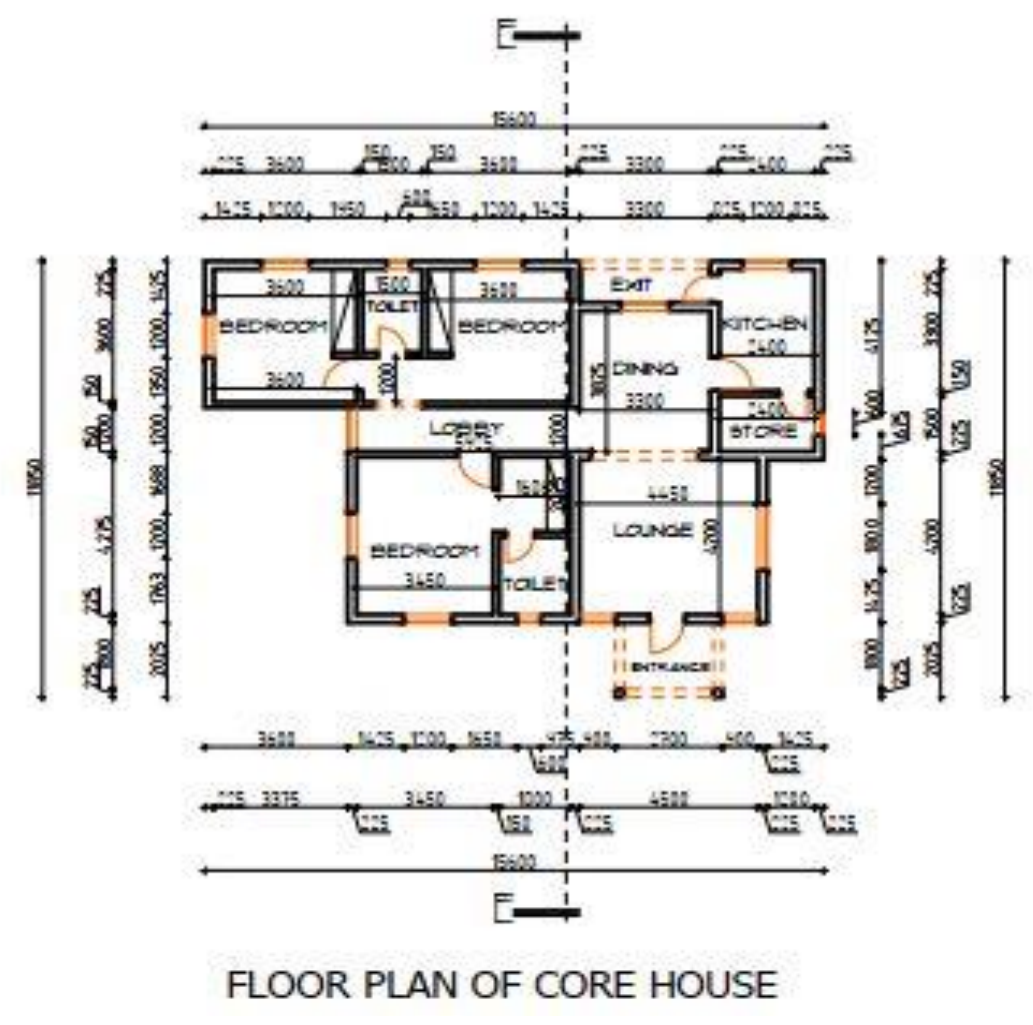

Figre 23: Floor Plan of the Detached 3- bedroom bungalow (Core House) at ASHDC Ngozika Housing Estate, Phase 1, Ikwodiaku, Awka (NGOZIKA 3)

Source: Field Work (2017). Reproduced from Archival Records of Anambra State Housing Development Corporation, Awka.

Figure 17 is the floor plan of the Detached 3-bedroom bungalow (Core House) at ASHDC) Ngozika Housing Estate, Phase 1, Ikwodiaku, Awaka (NGOZIKA 1). 


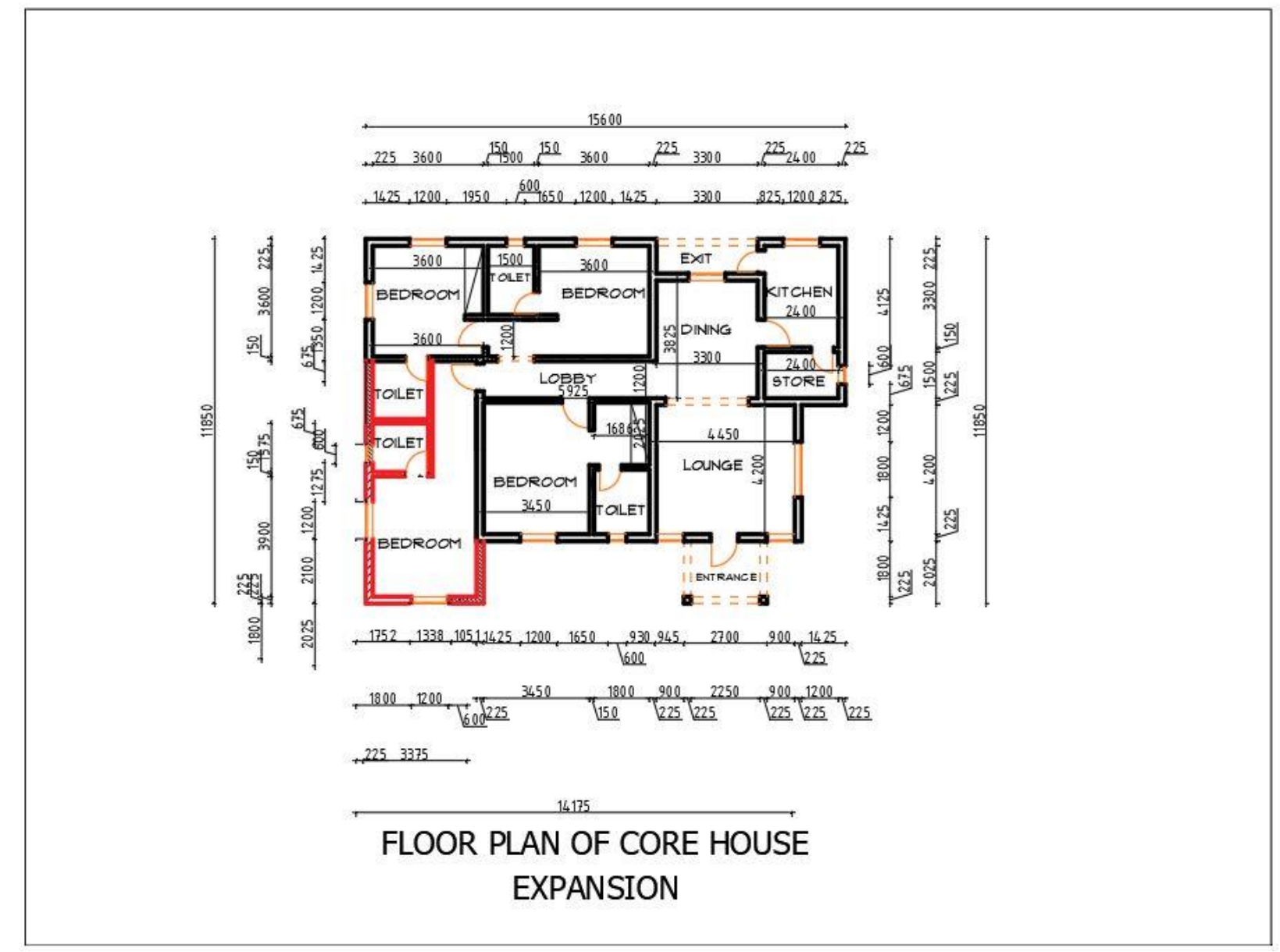

Figure 24: Floor plan for Core House Expansion, the Detached 3- bedroom bungalow (Core House) at ASHDC Ngozika Housing Estate, Phase 1, Ikwodiaku, Awka (NGOZIKA 3)

Source: Field Work (2017). Reproduced from Archival Records of Anambra State Housing Development Corporation, Awka.

Figure 18 is the floor plan core house expansion of the Detached 3-bedroom bungalow (Core House) at ASHDC Ngozika Housing Estate, Phase 1, Ikwodiaku, Awaka (NGOZIKA 1). 


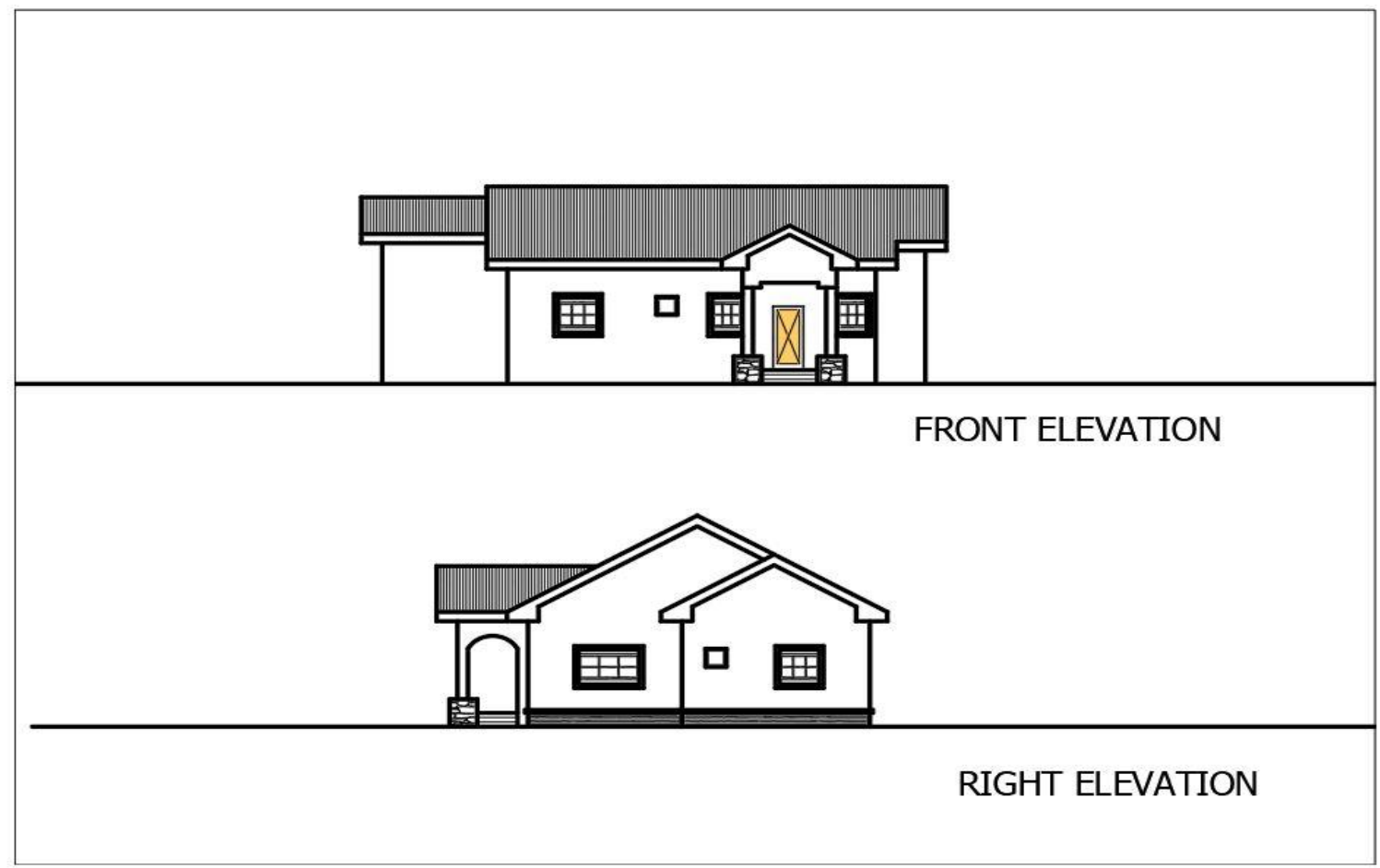

Figure 25: Front and Right Side Elevations of the Detached 3- bedroom Bungalow (Core House) at ASHDC Ngozika Housing Estate, Phase 1, Ikwodiaku, Awka (NGOZIKA 3)

Source: Field Work (2017). Reproduced from Archival Records of Anambra State Housing Development Corporation, Awka.

Figure 19 is the floor plan core house expansion of the Detached 3-bedroom bungalow (Core House) at ASHDC Ngozika Housing Estate, Phase 1, Ikwodiaku, Awaka (NGOZIKA 1). 
(b) Photographic image

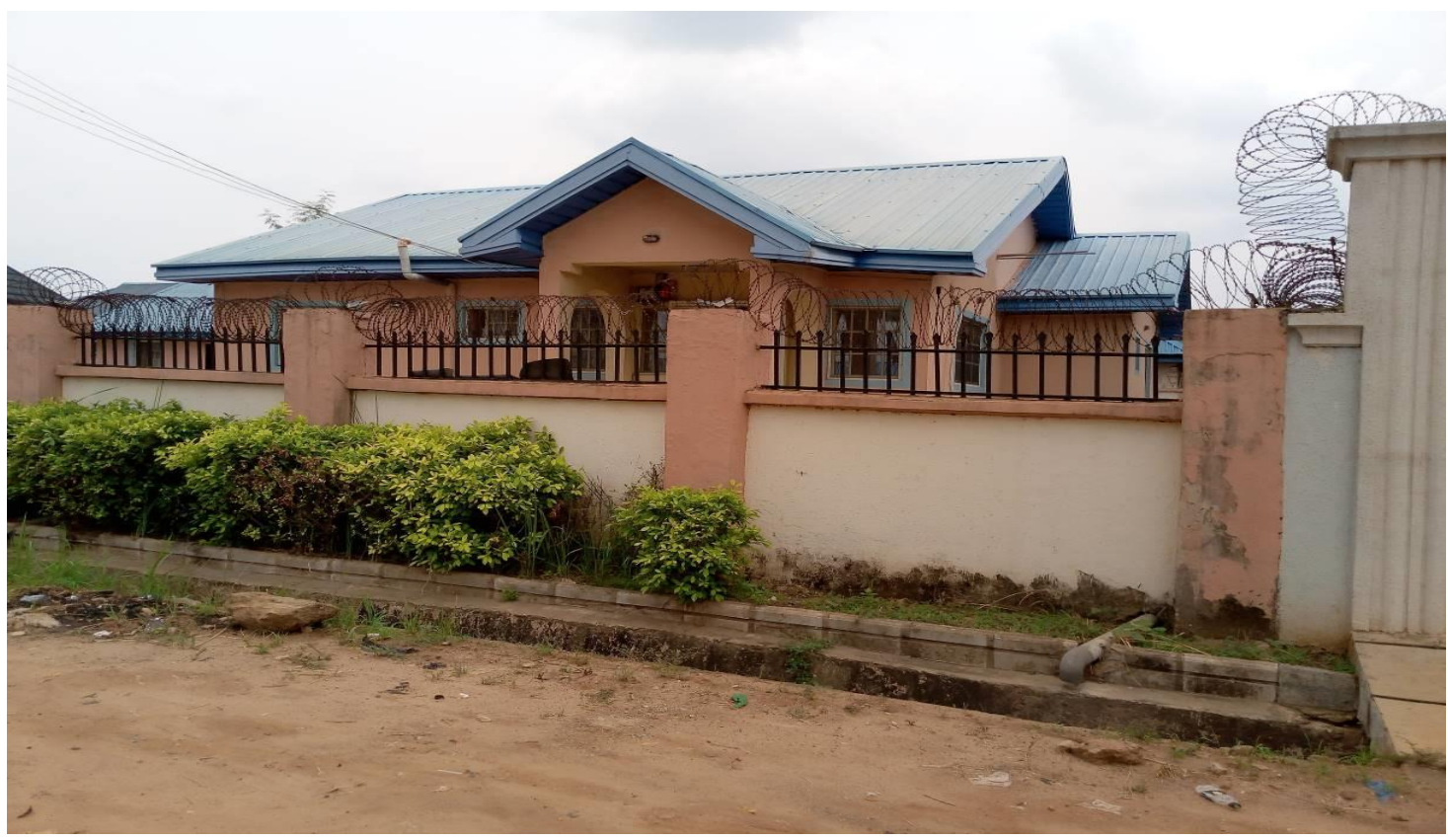

Plate 9: Detached 3 - bedroom bungalow (Core House) at ASHDC Ngozika Housing Estate, Phase 1, Ikwodiaku, Awka (NGOZIKA 3) showing Cement Block Wall Material and longspan aluminum as Roof Covering

(c) Building materials/finishes specification schedule

Table 9 shows the building materials/finishes specification schedule of the Detached 3bedroom bungalow (Core House) at ASHDC Ngozika Housing Estate, Phase 1, Ikwodiaku, Awaka (NGOZIKA 1).

Table 9: Building Materials/Finishes Specification Schedule

\begin{tabular}{ll}
\hline Building Element & Building Material/Finish \\
\hline Wall & $150 \mathrm{~mm}$ sandcrete block \\
Roof covering & $.45 \mathrm{~mm}$ longspan aluminium roofing sheets \\
Floor finish & Ceramic tiles \\
\hline
\end{tabular}

Source: Fieldwork (2017). Compiled from the Architectural Drawings of Existing Core House Prototype obtained from Anambra State Housing Development Corporation, Awka and Field Observation. 
(c) Result on asertaining the attribute "design simplicity" in architectural design" of the Detached 3- bedroom bungalow at ASHDC Ngozika Housing Estate, Phase 1, Ikwodiaku, Awka (NGOZIKA 3)

\section{(i) Variable 1 - Simplicity in size of initial floor area (SSF)}

As can be seen from Figure 22, the initial floor space (area built) of the prototype is 184.08 $\mathrm{m}^{2}$, which is the size of the dwelling unit (dwelling for one family) as the prototype is a detached housetype, meaning that it is meant for one household only. This is higher than the recommended $36 \mathrm{~m}^{2}$ size in literature as a component of design simplicity in architectural design of core housing schemes (Ike, 1996; Pandelaki and Shiozaki, 2010). The prototype is rated No for this variable.

\section{(ii) Variable 2 - Simplicity in shape of initial floor plan (SSP)}

Though the prototype has a simple geometric shape (rectangle), it has a lot of pronounced projections and depressions for its floor plans and as such does not exhibit design simplicity in architectural design of core housing schemes (Ike, 1996; Widewalls Editorial, 2017). This can be seen in Figure 23. The prototype is rated No for this variable.

\section{(iv) Variable 3 - Simplicity in specification for roof covering (SSR)}

Longspan aluminum roofing sheet is the roof covering of the prototype, as can be seen in Table 9 and Plate 9 rather than corrugated asbestos roofing sheet or clay tile types recommended in literature as a component of design simplicity in architectural design of core housing schemes (Pandelaki and Shiozaki, 2010; Atamewan and Olagunju, 2017). The prototype is rated No for this variable.

Below is the summary of the results on ascertaining design simplicity in architectural design of the existing public core house prototypes in Anambra State, Nigeria.

\section{(i) Semi-detached 3- bedroom bungalow at AHOCOL Phase 1 (AHOCOL 1)}

The three variables used to measure simplicity in architectural design of the existing core house prototypes, namely: (i) simplicity in size of initial floor area; (ii) simplicity in shape of initial floor plan; and (iii) simplicity in specification for roof covering have a rating of No, Yes and Yes respectively. This prototype, Semi-detached 3- bedroom bungalow (AHOCOL 1) was therefore rated Yes for design simplicity.

\section{(ii) Semi-detached 3- bedroom bungalow at AHOCOL Phase 2 (AHOCOL 2)}

The three variables used to measure simplicity in architectural design of the existing core house prototypes, namely: (i) simplicity in size of initial floor area; (ii) simplicity in shape of initial floor plan; and (iii) simplicity in specification for roof covering have a rating of No, Yes and Yes respectively. This prototype, Semi-detached 3- bedroom bungalow (AHOCOL 2) was therefore rated Yes for design simplicity. 
(iii) Detached 3- bedroom bungalow at AHOCOL Oganiru Housing Estate, Agu-Awka (AHOCOL 3)

The three variables used to measure simplicity in architectural design of the existing core house prototypes, namely: (i) simplicity in size of initial floor area; (ii) simplicity in shape of initial floor plan; and (iii) simplicity in specification for roof covering have a rating of No, Yes and Yes respectively. This prototype, Detached 3- bedroom bungalow at AHOCOL Oganiru Housing Estate, Agu-Awka (AHOCOL 3) was therefore rated Yes for design simplicity.

(iv) Detached 2- bedroom bungalow at AHOCOL Inner City Layout, Nkwelle, Awka (AHOCOL 4)

The three variables used to measure simplicity in architectural design of the existing core house prototypes, namely: (i) simplicity in size of initial floor area; (ii) simplicity in shape of initial floor plan; and (iii) simplicity in specification for roof covering have a rating of No, Yes and Yes respectively. This prototype, Detached 2- bedroom bungalow at AHOCOL Inner City Layout, Nkwelle, Awka (AHOCOL 4) was therefore rated Yes for design simplicity.

(iv) Detached 1- bedroom bungalow at ASHDC Ngozika Housing Estate, Phase 1, Ikwodiaku, Awka (NGOZIKA 1)

The three variables used to measure simplicity in architectural design of the existing core house prototypes, namely: (i) simplicity in size of initial floor area; (ii) simplicity in shape of initial floor plan; and (iii) simplicity in specification for roof covering have a rating of No, Yes and No respectively. This prototype, Detached 1- bedroom bungalow at ASHDC Ngozika Housing Estate, Awka (NGOZIKA 1) was therefore rated No for design simplicity.

\section{(v) Detached 2- bedroom bungalow at ASHDC Ngozika Housing Estate, Phase 1,} Ikwodiaku, Awka (NGOZIKA 2)

The three variables used to measure simplicity in architectural design of the existing core house prototypes, namely: (i) simplicity in size of initial floor area; (ii) simplicity in shape of initial floor plan; and (iii) simplicity in specification for roof covering have a rating of No, Yes and No respectively. This prototype, Detached 2- bedroom bungalow at ASHDC Ngozika Housing Estate, Awka (NGOZIKA 2) was therefore rated No for design simplicity.

(vi) Detached 3- bedroom bungalow at ASHDC Ngozika Housing Estate, Phase 1, Ikwodiaku, Awka (NGOZIKA 3)

The three variables used to measure flexibility in space use, namely: (i) flexibility in use of sitting room also for dining; (ii) flexibility in use of kitchen also for food storage; and (iii) flexibility in sub-division of internal spaces after ocupation have a rating of No, No and No respectively. This prototype, Detached 3- bedroom bungalow at ASHDC Ngozika Housing Estate, Awka (NGOZIKA 3) was therefore rated No for for design simplicity.

The summary of the result on ascertaining if design simplicity is reflected in architectural design of existing public core housing schemes in Anambra State is shown in Table 10. The result indicates design simplicity being reflected only in 3 out of the 7 existing public core house prototypes in Anambra State studied. The attribute is not reflected in the majority (4 of 
the prototypes). Out of a total 230 also, design simplicity is reflected only in $87(38 \%)$ of them. It is not reflected in $147(62 \%)$ them. The following are the prototypes where design simplicity is not reflected: (i) detached 2-bedroom bungalow at AHOCOL Inner City Layout, Nkwelle, Awka - 0 out of 3 dwelling units (ii) detached 1-bedroom bungalow at ASHDC Ngozika Housing Estate, Phase 1, Ikwodiaku, Awka, (NGOZIKA 1) - 0 out of 49 dwelling units; (iii) detached 2-bedroom bungalow at ASHDC Ngozika Housing Estate, Phase 1, Ikwodiaku, Awka, (NGOZIKA 2) - 0 out of 45 dwelling units; and (iv) detached 3-bedroom bungalow at ASHDC Ngozika Housing Estate, Phase 1, Ikwodiaku, Awka, (NGOZIKA 3) 0 out of 46 dwelling units. Futhermore, it can be seen from the Figures and Plates displayed in the results that the prototypes appear more like full-provision/finished houses instead of partial-provision types which core houses are.

The summary of result also shows variable 1 (simplicity in size of initial floor area - SSF) being reflected in non $(0 \%)$ of the 230 core housing units studied because they all have built areas in excess of the $36 \mathrm{~m}^{2}$ mark recommended in literature. Concerning variable 2 (simplicity in shape of initial floor plan - SSP), a majority of $184(80 \%)$ of the 230 core housing units studied have simple geometric shapes (rectangles) without pronounced projections and depressions for their floor plans as recommended in literature. Therefore, simplicity in shape of initial floor plan is reflected in the core housing units studied. In the case of variable 3 (simplicity in specification for roof covering - SSR) only 90 (39\%) of the 230 core housing units studied have either corrugated asbestos sheets or clay tiles as roof covering. Simplicity in specification for roof covering is not reflected in the core housing units studied.

Table 10: Summary of Result on Ascertaining if Design Simplicity is reflected in Architectural Designs of Existing Public Core Housing Schemes in Anambra State.

\begin{tabular}{|c|c|c|c|}
\hline $\mathbf{S} / \mathbf{N}$ & Prototype & $\begin{array}{l}\text { Ratings for the } 3 \\
\text { Variables for } \\
\text { Measuring Design } \\
\text { Simplicity } \\
\text { SSF SSP SSR }\end{array}$ & $\begin{array}{c}\text { Number of Core House } \\
\text { Prototypes Reflecting or } \\
\text { not Reflecting Design } \\
\text { Simplicity }\end{array}$ \\
\hline 1. & $\begin{array}{l}\text { Semi-detached 3-bedroom at } \\
\text { AHOCOL Phase } 1 \text { (AHOCOL 1) }\end{array}$ & $\begin{array}{l}\text { No, Yes, Yes } \\
\text { YES }\end{array}$ & $\begin{array}{l}\text { No } \text { Yes } \\
\text { 0 } 19\end{array}$ \\
\hline 2. & $\begin{array}{l}\text { Semi-detached 3-bedroom at } \\
\text { AHOCOL Phase } 2 \text { (AHOCOL 2) }\end{array}$ & $\begin{array}{l}\text { No, Yes, Yes } \\
\text { YES }\end{array}$ & 42 \\
\hline 3. & $\begin{array}{l}\text { Detached 3-bedroom at } \\
\text { AHOCOL Oganiru Housing } \\
\text { Estate, Agu-Awka (AHOCOL 3) }\end{array}$ & $\begin{array}{l}\text { No, Yes, Yes } \\
\text { YES }\end{array}$ & 26 \\
\hline 4. & $\begin{array}{l}\text { Detached 2-bedroom at } \\
\text { AHOCOL Inner City Layout, } \\
\text { Nkwelle, Awka AHOCOL } 4\end{array}$ & $\begin{array}{l}\text { No, Yes, Yes } \\
\quad \text { NO }\end{array}$ & 3 \\
\hline 5. & $\begin{array}{l}\text { Detached 1-bedroom at ASHDC } \\
\text { Ngozika Housing Estate, Phase } \\
\text { 1, Ikwodiaku, Awka } \\
\text { (NGOZIKA 1) }\end{array}$ & $\begin{array}{l}\text { No, Yes, No } \\
\text { NO }\end{array}$ & 49 \\
\hline
\end{tabular}


6. Detached 3-bedroom at ASHDC

Ngozika Housing Estate, Phase

1, Ikwodiaku, Awka (NGOZIKA

2)

7. Detached 3-bedroom at ASHDC

Ngozika Housing Estate, Phase

1, Ikwodiaku, Awka (NGOZIKA

3)

Total

Source: Field Work (2017)

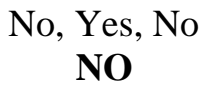

No, Yes, No

NO

No, No, No

NO

0 18490
450

460

14387

\section{Findings}

\section{Objective 1: to review literature on design simplicity in architectural design of core housing schemes}

From literature review (Okoye, Onyegiri \& Okafor, 2021), the following variables were found to be be three variables of greatest interest in simplicity in architectural design of core housing schemes in Anambra State, namely: (i) simplicity in size of initial floor area; (ii) simplicity in shape of initial floor plan; and (iii) simplicity in specification for roof covering.

\section{Objective 2: to ascertain if design simplicity is reflected in architectural design of existing public core housing schemes in Anambra State}

The summary of the result of this study has shown that out of the 7 existing public core house prototypes in Anambra State studied, design simplicity was found not reflected in the majority (4 numbers), having a total of $143(62 \%)$ out of the 230 prototypes studied. The prototypes that do not have simplicity in architectural design reflected in them and the number of dwelling units are: (i) detached 2-bedroom bungalow at AHOCOL Inner City Layout, Nkwelle, Awka - 0 out of 3 dwelling units (ii) detached 1-bedroom bungalow at ASHDC Ngozika Housing Estate, Phase 1, Ikwodiaku, Awka, (NGOZIKA 1) - 0 out of 49 dwelling units; (iii) detached 2-bedroom bungalow at ASHDC Ngozika Housing Estate, Phase 1, Ikwodiaku, Awka, (NGOZIKA 2) - 0 out of 45 dwelling units; and (iv) detached 3bedroom bungalow at ASHDC Ngozika Housing Estate, Phase 1, Ikwodiaku, Awka, (NGOZIKA 3) - 0 out of 46 dwelling units. The summary of result also shows variable 1 (simplicity in size of initial floor area - SSP) being reflected in non $(0 \%)$ of the 230 core housing units studied because they all have built areas in excess of the $36 \mathrm{~m}^{2}$ mark recommended in literature. Concerning variable 2 (simplicity in shape of initial floor plan SSP), $184(80 \%)$ of the 230 core housing units studied have simple geometric shapes (rectangles) without pronounced projections and depressions for their floor plans as recommended in literature. In the case of variable 3 (simplicity in specification for roof covering - SSR) 90 (39\%) of the 230 core housing units studied have either corrugated asbestos sheets or clay tiles as roof covering.

It is the finding of this study therefore that design simplicity is not reflected in the architectural design of existing public core housing schemes in Anambra State. Additionally, 
the core house prototypes studied take the semblance of full provision/ finished houses rather than core houses as can be seen from the architectural drawings and photographic images of the prototypes.

\section{DISCUSSION}

In the introductory section of this study, two objectives were proposed for accomplishment. The first concerns a review of literature on design simplicity in architectural design of core housing schemes, while the second is on ascertaining if it is reflected in architectural design of the existing public core housing schemes in Anambra State. With respect to the first objective, the findings of the study have established what variables (characteristics) constitute design simplicity in architectural design of core housing schemes, namely: (i) simplicity in size of initial floor area (SSF); (ii) simplicity in shape of initial floor planSSP); and (iii) simplicity in specification for roof covering (SSR). The considerations are deemed apt in that they contribute towards the reduction of size of building (compact spaces), utilization of shapes that are easy and straight-forward in construction and building materials that have affordability advantage. The volume of literature reviewed show simplicity in architectural design as an attribute ensuring accomplishment in design of compact spaces for the initial core units with simple shapes and specifications of affordable materials (mainly local). Findings from previous studies have shown that this attribute promotes affordability of core housing. This is because the design of the compact core unit is intended to bring down the house price of the initial habitable unit and hence its affordability.

The other objective ascertained if design simplicity is reflected in architectural design of existing public core housing schemes in Anambra State. The findings of the study show that it is deficient in these schemes. This is contrary to Abrams (1964), Ike (1996), Faculty of Engineering and Architecture, University of Khartoum, Sudan (FEAUKS, 2010), Pandelaki and Shiozaki (2010), Gattoni, Goethert and Chavez (2011), Breimer (2011), Atamewan and Olagunju(2017) and Okoye, Onyegiri and Okafor (2021), who reported and stressed the importance of the various components of design simplicity in the conception of low-cost housing schemes and core housing schemes particularly, because of the affordability advantage of evolving compact spaces, simple shapes and affordable building materials. The deficiency in design simplicity equally falls short of the implications of Maslow's Hierarchy of Needs theory on provision of basic shelter need, simple shelter for the primary function of protection as the basic need of housing users before setting out for the needs. This is more important in low-cost housing where core housing belongs. Possible reasons underlining the findings could be that the designers did not have necessary information on what to look out for in carrying out their designs in a form that would have improved the affordability of the prototypes. Further explanations on the shortfalls or conformity, as the case may be, are given below according to the variables.

The findings showing variable 1 (simplicity in size of initial floor area - SSF) being reflected in non $(0 \%)$ of the 230 core housing units studied falls short of the recommendations of Ike (199) and Pandelaki and Shiozaki (2010) on the importance of reduction of initial floor space (area built) in core houses and that the area should not be more than $36 \mathrm{~m}^{2}$. It as well deviates from the postulations of Maslow's Hierarchy of Needs theory on the priority of taking care of basic housing need first before proceeding to other ones. This occurrence could be because, 
though they are meant to be core houses, the houses were erroneously designed as full provision/finished houses probably out of ignorance of vital information. Concerning variable 2 (simplicity in shape of initial floor plan - SSP), 184 (80\%) of the 230 core housing units studied have simple geometric shapes (rectangles) without pronounced projections and depressions for their floor plans as recommended in literature. This is in conformity with Ike (1996); Bradley (2011) and Widewalls Editorial (2017)'s recommendations of simple geometric shapes for improving affordability of core housing. The compliance in adoption of simple geometric shapes could be because complicated shapes such as circles and hexagons, for instance, have not been conventional in public housing designs so the designers naturally inclined to simple geometric shapes. In the case of variable 3 (simplicity in specification for roof covering - SSR), the fact that only 90 (39\%) of the 230 core housing units studied have either corrugated asbestos sheets or clay tiles as roof covering, majority (61\%) having the high quality type (longspan aluminum sheet) is diverse from the recommendations of Ike (1996), Napier (2002), Pandelaki \& Shiozaki (2010), Pandelaki and Shiozaki (2010) and Atamewan and Olagunju (2017) on reducing the quality of building materials/finish specification in order to improve affordability. The specification for longspan aluminium sheet could be because the designers were more concerned with the aesthetics and durability of the roof covering than the affordability issue. The deficiency of these conditions indicates that the prototypes were really not designed to meet requirements for design simplicity probably because knowledge was obscure. This is not surprising since majority of them, as earlier mentioned, take the form of full provision/ finished houses, although they are supposed to be core houses. The lack this attribute "design simplicity" apparently would have affected the non-affordability of the prototypes for the intended residents as found in Okoye, Onyegiri and Okafor, 2021.

\section{CONCLUSION}

The background to this study is on the basis of the knowledge that though architectural design characteristics affecting design simplicity have been found to positively influence core housing affordability, it has not been known if they are properly reflected in the design of existing core housing schemes. This is seemingly true for the study area, Anambra State, where record is lacking on how this important attribute has been represented in public core house prototypes developed in the state. The study therefore began by reviewing relevant literature on the attribute design simplicity in relation to core housing affordability and establishing its variables (characteristics). It then ascertained the reflection of this attribute in architectural design of the existing public core housing schemes in Anambra State. The findings of the study explained design simplicity in relation to core housing affordability and established the main variables characterizing it to incorporate: (i) simplicity in size of initial floor area; (ii) simplicity in shape of initial floor plan; and (iii) simplicity in specification for roof covering. The study found design simplicity lacking in the existing public core house protoypes in Anambra State and that the prototypes appear more like full-provision/finished houses than core houses. The study is of the opinion that it is probably as a result of obscurity of knowledge that this attribute has not been duely considered in the design of the core houses. It therefore contributes in furthering knowledge in this area and recommends due and strict consideration of the variables constituting design simplicity in the planning of future core housing schemes in Anambra State and environs. This study will be of immense assistance to researchers and stakeholders of the built environment. 


\section{REFERENCES}

Abrams, C. (1964). Man's struggle for shelter in an urbanizing world. Cambridge, M. I. T Press, 1-2, 174-181.

Ajanlekoko, J. (2001). Sustainable housing development in Nigeria: The financial and infrastructural implication. International Conference on Spatial Information for Sustainable Development, (pp. 1-13,19). Nairobi, Kenya.

Atamewan, E. E., \& Olagunju, R. E. (2017). Incremental construction for sustainable lowincome housing delivery in developing countries: A case study of Bayelsa State, Nigeria. Journal of Sustainable Architecture and Engineering, 20-38.

Aucamp, C. A., \& Moodley, G. Y. (2002). Making low-cost housing projects more accessible for public tranport in Ethekwini, South Africa: What are the costs? Traffic and Transport Department, City Engineers' Unit, Durban 4000

Balchin, P. R., Isaac, D., \& Chen, J. (2000). Urban economics: A global perspective. New York: Palgrave.

Bradley, S. (2011). Design Fundamentals.

Breimer, T. (2011). Open building as an approach for more effective core housing implimenation? An exploration. Masters Degree Progrmme in Urban Management and Development, Lund University. Retrieved 2011

Eni, C. (2015). Establishment of strategies for improving affordable and habitable public housing provision in Anambra state Nigeria. British Journal of Environmental Sciences, 3(1), 23-42. Retrieved from www.eaJournals.org

Esenwein, F. (2016). Simply American: simplicity in Architectural arrangement, construction and standard. published Ph. D Thesis, University of Pennsylvania, U.S.A.

Faculty of Engineering and Architecture, University of Khartoum, Sudan- FEAUKS. (2010). Incremental housing: Its potentials and limitations, evidence from Khartoum, Sudan. Santander, Spain: World Congress on Housing.

Feins, J. D., \& Lane, T. S. (1981). How much for housing? New perspectives on affordability and risk. Abt Books.

Gattoni, G., Goethert, R., \& Chavez, R. (2011). Self-help and incremental housing: Likely directions for future policy. Research Report, Universidad Jose Simeon Canas and Universidad de El Salvador.

Goethert, R. (2010). Incremental housing. a pro-active urban strategy. Incremental Housing Bulletin.

Greene, M., \& Rojas, E. (2008). Incremental construction: A strategy to facilitate access to housing. Environment and Urbanization, 20(1), 19.

Grimmes, O. (1976). Housing for low-income urban families. The John Hopkins University. World Bank Research Publication.

Gudeta, H. A. (2010). An assessment of urban housing supply and affordability in Jimma Town: with reference to condominium housing. M.A Thesis, Institute of regional and local development studies.

Hancock, K. E. (1993). 'Can pay? Won't pay?' or economic principles of affordability. Urban Studies, 30(1), 127-145.

Ibem, E. O., Aduwo, E. B., \& Ayo-Vaughan, E. K. (2015). Assessment of the Sustainability of Public Housing projects in Ogun State, Nigeria: A post-occupancy evaluation approach. Mediterranean Journal of Social Sciences, 6(452), 523-533. Retrieved July 2015. 
Ibem, E. O., Anosike, M. N., \& Azuh, D. E. (2011). Challenges in public housing provision in the post-independence era in Nigeria. International Journal of Human Sciences, 8(2), 422-441. Retrieved September 8, 2016, from ISSN: 1303-5134.

Ike, E. (1996). Affordable homes: A guide to easy home-building. Lagos: The Show Kemt Ltd.

Irouke, V. M., Ajah, M., \& Ivoke, H. I. (2017). An evaluation of shagari housing programme: case study of three towns - Abakaliki in Ebonyi State, Lokoja in Kogi State and Mbano in Imo State, Nigeria. IIARD, International Journal of Geography and Environmental Management, 3(3), 2504-8821. Retrieved 2017, from www.iiardpub.org

Kolli, H., \& Putta, V. (2014). Evaluation of public housing schemes: A case of greater hyderabad municipal corporation. Research Gate. Retrieved October 2014

Maly, E., \& Tamyo, K. (2012). An incrementally expandable core house for disaster reconstruction: Two cases in Yogyakarta, Indonesia, After the Central Java Earthquake. Memoirs of Graduate School of Engineering and Systems Informatics, 4, pp. 1-7.

Maslow, A. H. (1970). Motivation and Personality. New York: Harper and Row

Milligan, V. R. (2003). How different? comparing housing policies and housing affordability consequences for low-income households in Australia and the Netherlands. Utrecht, Sydney: Labor Grafimedia b. v.

Mutisya, K. R. (2015). Housing affordability in Kenya: A case Study of the mortgage housing sector in nairobi. School of Built Environment, University of Nairobi, Kenya,

Department of Real Estate and Construction Manangement. Retrieved August 2015

Napier, M. (2002). Core housing, enablement and urban poverty: The consolidation paths of households living in two South Saharan African settlement. ph.D Thesis, University of Newcastle upon Tyne. Retrieved 2012, from http:/www.urbanlandmark.org.za

National Population Commision of Nigeria. (2006). National population census of Nigeria, Federal Republic of Nigeria.

Ndubueze, O. J. (2009). Urban housing affordability and housing policy dilemmans in Nigeria. University of Brbaughan. Centre for Urban and Regional Studies, School of Public Policy.

Nwuba, C. C. (2015). Developing a model for measurement of urban incremental housing affordability in Kaduna State, Nigeria. University of Nigeria, Enugu Campus, Enugu, Nigeria, Department of Estate Manangement, Faculty of Environmental Studies. Retrieved 2019

Okoye, N.B.C.D., Onyegiri, I. \& Okafor, M. (2021), Effect of Architectural Design Characteristics Affecting Design Simplicity on Affordability Improvement of Core Housing Schemes. Journal of Advanced Research and Multidisciplinary Studies 1(1), 26-34. DOI: 10.52589/JARMS9P4A2M5S. Retrieved June, 2021.

Onah, F. O. (2015). Human Resource Management (4th ed.). Enugu: John Jacob's Classic Publishers Ltd.

Pandelaki, E., \& Shiozaki, Y. (2010). The core house concept and its implementation in indonesia, past, present, future. International Journal for Housing Science, 34(44), 233248. Retrieved December, 2017.

Sharipah, N., \& Sidi, S. (2011). Quality affordable housing: A theoretical framework for planning and design of quality housing. Journal of Techno-SocialMy JournalMalaysian Citation Centre, 1-10. Retrieved from www.myjournal.my/public/issueviewphp?id=2787\& 
Stohr, K. (2005). '100 Years of humanitarian design', Architecture for humanity (ed.), in: Design like you give a damn. Architectural Responses to Humanitarian Crises. Thames \& Hudson, London (U.K.).

Udoh, U. P. (2018). Housing policy as a tool for addressing rural housing challenges in Nigeria. Journal of Law, Policy and Globalization, 71, 5-6. Retrieved 2018

Ugonabo, C., \& Emoh, F. (2013). The major challenges to housing development and delivery in Anambra State of Nigeria. Civil and Environmental Research Journal, 3(4).

United Nations Human Settlements Programme, UN-HABITAT. (2009). Structural plans for Awka and Satellite Towns. Retrieved November 16, 2017, from http://www.unhabitat.org

Widewalls Editorial. (2017). Art, history and minimalism.

World Bank. (2018). Nigeria affordable housing project. Documentation/Integrated Safeguards Data Sheet (PID/ISDS).

Zavei, S. J., \& Jusan, M. M. (2012). Exploring housing attributes selection based on maslow's hierarchy of needs. Prcedia-Social and Behavioural Sciences, 42, 311-319 


\section{APPENDIX A}

\section{OBSERVATION SCHEDULE:}

Objective 2: Ascertaining the Reflection of Design Simplicity in Architectural Design of the Existing Core House Prototypes in Anambra State

Prototype:

\begin{tabular}{clllll}
\hline S/N & $\begin{array}{l}\text { Variable } \\
\text { Number }\end{array}$ & Variable Description & $\begin{array}{l}\text { Variable } \\
\text { Code }\end{array}$ & Status & \\
\hline & & For General Information & & YES & NO \\
\hline & Design simplicity & & \\
1. & V3 & Simplicity in size of initial floor area & SSF & \\
4. & V4 & $\begin{array}{l}\text { Simplicity in shape of initial floor } \\
\text { plan }\end{array}$ & SSP & \\
5. & V5 & $\begin{array}{l}\text { Simplicity in specification for roof } \\
\text { coveFring }\end{array}$ & SSR & \\
& & & &
\end{tabular}

\section{APPENDIX B}

\section{INTERVIEW GUIDE: PILOT SURVEY}

Interview with the Head of Estate Management Department, Anambra State Housing Development Corporation, Awka, Anambra State.

Length of Time: $25-30$ minutes.

Goal: To obtian knowledge on issues of concern to this research from your point of view, based on your experience.

1. Name:

2. Establishment:

3. Department:

4. Designation: 
5. The Anambra State housing provision policy is based on:

(i) Outright purchase of houses

(ii) Sites and services programme

(iii) Mortgage arrangement

\section{APPENDIX C}

\section{INTERVIEW GUIDE: PILOT SURVEY}

Interview with the Head of Quantity Surveying Department, Anambra State housing Development Corporation, Awka, Anambra State.

Length of Time: $25-40$ minutes.

Goal: To obtain knowledge on issues of concern to this research from your point of view, based on your experience.

1. Name:

2. Establishment:

3. Department:

4. Designation:

5. The land/building costs of 1-bedroom, 2-bedroom and 3-bedroom fullprovision/finished house types within Awka city as at the year 2016?

(i)

(ii)

(iii) 